\title{
Precision-feeding dairy heifers a high rumen-degradable protein diet with different proportions of dietary fiber and forage-to-concentrate ratios
}

\author{
G. J. Lascano, ${ }^{* 1}$ L. E. Koch, ${ }^{*}$ and A. J. Heinrichs† \\ *Department of Animal and Veterinary Sciences, Clemson University, SC 29634 \\ †Department of Animal Sciences, The Pennsylvania State University, University Park 16802
}

\begin{abstract}
The objective of this experiment was to determine the effects of feeding a high-rumen-degradable protein (RDP) diet when dietary fiber content is manipulated within differing forage-to-concentrate ratio (F:C) on nutrient utilization of precision-fed dairy heifers. Six cannulated Holstein heifers $(486.98 \pm 15.07 \mathrm{~kg}$ of body weight) were randomly assigned to $2 \mathrm{~F}$ :C, low- (45\% forage; $\mathrm{LF}$ ) and high-forage (90\% forage; $\mathrm{HF}$ ) diets and to a fiber proportion sequence [33\% grass hay and wheat straw (HS), $67 \%$ corn silage (CS; low fiber); $50 \%$ HS, $50 \%$ CS (medium fiber); and 67\% HS, $33 \%$ CS (high fiber)] within forage proportion administered according to a split-plot, $3 \times 3$ Latin square design (16-d periods). Heifers fed LF had greater apparent totaltract organic matter digestibility coefficients (dC), neutral detergent fiber, and cellulose than those fed LC diets. Substituting CS with HS resulted in a linear reduction in dry matter, organic matter, and cellulose dC. Nitrogen dC was not different between F:C or with increasing proportions of $\mathrm{HS}$ in diets, but $\mathrm{N}$ retention tended to decrease linearly as HS was increased in the diets. Predicted microbial protein flow to the duodenum decreased linearly with HS addition and protozoa numbers HS interacted linearly, exhibiting a decrease as HS increased for LF, whereas no effects were observed for HF. Blood urea N increased linearly as HS was incorporated. The LF-fed heifers had a greater ruminal volatile fatty acids concentration. We noted a tendency for a greater dry matter, and a significantly higher liquid fraction turnover rate for HF diets. There was a linear numerical increase in the liquid and solid fraction turnover rate as fiber was added to the diets. Rumen fermentation parameters and fractional passages (solid and liquid) rates support the reduction in $\mathrm{dC}$, $\mathrm{N}$ retention, and microbial protein synthesis observed as more dietary fiber is added to the rations of dairy
\end{abstract}

Received March 18, 2016.

Accepted May 20, 2016.

${ }^{1}$ Corresponding author: glascan@clemson.edu heifers precision-fed a constant proportion of rumendegradable protein.

Key words: heifer, dietary fiber, rumen-degradable protein, precision feeding

\section{INTRODUCTION}

The ruminant animal is unique in its ability to survive on a diet consisting entirely of NPN (Van Soest, 1994), but its growth cannot be sustained solely by rumen microbial protein synthesis (Merchen and Titgemeyer, 1992). Microbial protein contribution from RDP can represent from 50 to $80 \%$ of the AA absorbed (Storm and Orskov, 1983; Clark et al., 1992); hence, RUP is also needed to supply the required AA to the rapidly growing heifer. But, even when supplemental protein is provided, microbial protein synthesis must be maximized to take advantage of this unique characteristic (Johnson et al., 1998; Bach et al., 2005). Research on the effect of protein degradability in dairy heifer diets is scarce. Zanton and Heinrichs (2009) suggested an optimal $\mathrm{N}$ intake for heifers limit-fed either a high- or low-forage diet of $1.67 \mathrm{~g}$ of $\mathrm{N} / \mathrm{kg}$ of $\mathrm{BW}^{0.75}$, but protein rumen degradability was not assessed. Gabler and Heinrichs (2003) and Zanton et al. (2007) studied the effect of manipulating RDP in dairy heifers fed only high-forage diets (HF), and observed no difference in $\mathrm{N}$ utilization even when some fermentation parameters were affected. Both studies agreed that the effects observed were dependent on forage-to-concentrate ratios $(\mathbf{F}: \mathbf{C})$ and nutrient concentrations.

Precision feeding dairy heifers can be accomplished by modifying $\mathrm{F}: \mathrm{C}$ in numerous ways and can result in different dietary fiber proportions, thus changing the dynamics of how nutrients interact. Passage rates (kp) are typically higher in the growing heifer due to a smaller rumen capacity (Van Soest, 1994), affecting the synchrony at which nutrients are used at the rumen level. Additionally, $\mathrm{kp}$ can be slower when intake is limited, especially in low-forage diets (LF; Eng et al., 1964; Owens and Isaacson, 1977; Colucci et al., 1990), resulting in reduced rumen bacterial and feed $\mathrm{N}$ flow to the small intestine (Murphy et al. 1994). However, 
when optimal ruminal interaction between protein and carbohydrate has been achieved, results suggest improved nutrient utilization (Nocek and Russell, 1988). Hoover and Stokes (1991) reported increased ADG with an NSC-to-RDP ratio of 3.30 and hypothesized that synchronizing NSC-to-RDP ratios may increase AA flow to the small intestine and maximize the efficiency of protein used for growth. Similarly, CP-to-ME ratios of around $55 \mathrm{~g} / \mathrm{Mcal}$ per day have enhanced ADG and nutrient utilization (Lammers and Heinrichs, 2000; Gabler and Heinrichs, 2003).

In a recent study in which dairy heifers were precision-fed different dietary fiber proportions within 2 different $\mathrm{F}: \mathrm{C}$ treatments, $\mathrm{N}$ retention was increased quadratically in the LF diet whereas the opposite effect was observed for HF diets (Lascano and Heinrichs, 2011). Similar patterns in microbial protein flow to the duodenum and $\mathrm{N}$ retention suggest that, in a limited intake scenario, synchrony between fiber, $\mathrm{kp}, \mathrm{F}: \mathrm{C}$, and protein degradability can be manipulated to increase $\mathrm{N}$ utilization in dairy heifers. Therefore, the hypothesis of the current experiment was that high RDP would differentially improve $\mathrm{N}$ utilization depending on the fiber content $\mathrm{HF}$ and $\mathrm{LF}$ diets precision-fed to dairy heifers. The objective was to determine the effects of feeding a high-RDP diet when dietary fiber content is manipulated within differing $\mathrm{F}: \mathrm{C}$ on nutrient digestibility, nitrogen utilization, and rumen fermentation of precision-fed dairy heifers. An additional objective was to determine if fractional $\mathrm{kp}$ were affected by $\mathrm{F}: \mathrm{C}$ and incremental dietary fiber proportions under precision feeding conditions.

\section{MATERIALS AND METHODS}

\section{Animals and Experimental Design}

All procedures involving animals were approved by the Pennsylvania State University Institutional Animal Care and Use Committee. Six Holstein rumen-cannulated heifers, $15.56 \pm 0.45 \mathrm{mo}$ of age and $486.98 \pm$ $15.07 \mathrm{~kg}$ of BW, were randomly assigned to $2 \mathrm{~F}$ : C, LF ( $45 \%$ forage) and $\mathrm{HF}$ (90\% forage), and to a forage combination sequence to modify dietary fiber content [33\% of forage in proportionally equal combination of grass hay and wheat straw (HS), $67 \%$ corn silage (CS; low-fiber treatment); $50 \%$ HS, $50 \%$ CS (medium-fiber treatment); and 67\% HS, 33\% CS (high-fiber treatment)] within F:C. Heifers were assigned to a splitplot, $3 \times 3$ Latin square design with 16 -d periods. The whole-plot factor was the $\operatorname{diet} \mathrm{F}: \mathrm{C}$, and the subplot was fiber proportion within the forage fraction of the diet. Specifically, heifers were offered a basal HF or LF diet containing a low-, medium-, or high-fiber forage combi- nation. Similar N intake and RDP were provided (1.20 $\mathrm{g}$ of $\mathrm{N} / \mathrm{kg}$ of $\mathrm{BW}^{0.75}$ ), and casein was added to supply additional $\mathrm{N}$ to provide $1.80 \mathrm{~g}$ of $\mathrm{N} / \mathrm{kg}$ of $\mathrm{BW}^{0.75}$, which has been observed to maximize $\mathrm{N}$ utilization in dairy heifers (Zanton and Heinrichs, 2009). Diets were provided as a TMR and calculated to provide equal intakes of $\mathrm{ME}$ and to allow for $800 \mathrm{~g} / \mathrm{d}$ of ADG. Adaptation to treatment rations (dietary fiber) were made over the first $11 \mathrm{~d}$ of each period; on d 12, sample collection began. Basal diets are presented in Table 1. Heifer BW were measured daily $2 \mathrm{~h}$ before and weighted averages used to determine amount of feed offered for the following 8-d interval. Rations were mixed daily at $1200 \mathrm{~h}$ by preparing the LF and HF diets with the different fiber combinations individually. Heifers were fed daily at 1000, 1600, and $2400 \mathrm{~h}$ with sodium caseinate (American Casein Company, Burlington, NJ) added to the basal diet to obtain the RDP content proposed. Heifers were housed in individual stalls $(117 \times 302 \mathrm{~cm})$ in a mechanically ventilated tiestall barn with rubber mattress bedding and were allowed access to an exercise lot for $2 \mathrm{~h}$ before the $1000 \mathrm{~h}$ feeding on nonsampling days. Time (min) required to finish a meal was recorded, and water was available ad libitum with daily individual consumption monitored via unidirectional flow meters (Sensus Metering Systems, Uniontown, PA).

\section{Fecal, Urine, and Feed Sample Collection and Analysis}

Feces and urine were collected from d 12 to 14 (2 $\mathrm{d}$ of total collection). Urine was collected via modified urine device (Lascano et al., 2010), weighed, and subsampled daily after feeding. A 250-mL subsample was frozen at $-20^{\circ} \mathrm{C}$ for further analysis. Urine $\mathrm{pH}$ was monitored and acidified to $\mathrm{pH}<2$ by the addition of 12 $N \mathrm{HCl}$ as required to minimize $\mathrm{NH}_{3}$ volatilization (Zanton and Heinrichs, 2009). Feces were collected hourly and stored in airtight containers; every $24 \mathrm{~h}$ the total collection of feces was mixed, weighed, recorded, and subsampled. Feedstuffs, TMR, feces (dry basis), and urine (wet basis) were composited by period. Samples were dried in a $55^{\circ} \mathrm{C}$ forced-air oven for $4 \mathrm{~d}$, ground through a 1-mm screen using a Wiley Mill (Arthur H. Thomas, Philadelphia, PA), and analyzed for DM, OM, ash (AOAC International, 2000), ADF, ADL, and NDF (Van Soest et al., 1991) using an Ankom ${ }^{200}$ Fiber Analyzer (Ankom Technology Corporation, Fairport, NY), with heat-resistant $\alpha$-amylase and sodium sulfite used in the NDF procedure. Starch was analyzed on reground samples $(<0.5-\mathrm{mm}$ screen) using a modified procedure reported by Zanton and Heinrichs (2009). Freeze-dried feed and fecal samples were pulverized using Mixer Mill MM 200 (Retsch GmbH, Haan, Germany) and 
Table 1. Ingredient and chemical composition of low- (LF) or high-forage (HF) diets containing 3 proportions of fiber through the incorporation of fibrous feedstuffs $(33,50$, or $67 \%$ in the 45 or $90 \%$ forage fraction of the diet)

\begin{tabular}{|c|c|c|c|c|c|c|}
\hline \multirow[b]{2}{*}{ Item } & \multicolumn{3}{|c|}{$\mathrm{HF}$} & \multicolumn{3}{|c|}{$\mathrm{LF}$} \\
\hline & $33 \%$ & $50 \%$ & $67 \%$ & $33 \%$ & $50 \%$ & $67 \%$ \\
\hline \multicolumn{7}{|l|}{ Ingredient } \\
\hline Grass hav $^{1}$ & 15.00 & 22.50 & 30.00 & 7.50 & 11.25 & 15.00 \\
\hline Corn silage $^{2}$ & 60.00 & 45.00 & 30.00 & 30.00 & 22.50 & 15.00 \\
\hline Wheat straw ${ }^{3}$ & 15.00 & 22.50 & 30.00 & 7.50 & 11.25 & 15.00 \\
\hline Cracked corn & 0.02 & 1.50 & 1.93 & 26.60 & 27.80 & 28.06 \\
\hline Soy expellers & 5.78 & 4.19 & 2.33 & 3.65 & 2.85 & 2.90 \\
\hline Soybean meal & 0.78 & 0.50 & 1.68 & 6.35 & 6.02 & 5.69 \\
\hline Citrus pulp & 0.15 & 0.63 & 1.11 & 14.70 & 14.70 & 14.70 \\
\hline Casein & 0.00 & 0.00 & 0.00 & 0.00 & 0.00 & 0.00 \\
\hline Urea & 0.35 & 0.35 & 0.19 & 0.20 & 0.20 & 0.20 \\
\hline Molasses & 1.00 & 1.00 & 1.00 & 1.00 & 1.00 & 1.00 \\
\hline Sodium bicarbonate & 0.00 & 0.00 & 0.00 & 0.35 & 0.35 & 0.35 \\
\hline Mineral-vitamin $\operatorname{mix}^{4}$ & 1.92 & 1.83 & 1.76 & 2.15 & 2.08 & 2.10 \\
\hline \multicolumn{7}{|l|}{ Chemical composition ${ }^{5}$} \\
\hline DM, \% & 53.17 & 53.53 & 52.71 & 55.64 & 56.84 & 54.08 \\
\hline $\mathrm{CP}, \%$ & 11.44 & 10.66 & 10.46 & 12.67 & 12.43 & 12.17 \\
\hline Solubles, $\%$ of CP & 27.24 & 25.20 & 23.47 & 21.28 & 20.94 & 20.59 \\
\hline $\mathrm{RDP}, \%$ of $\mathrm{CP}$ & 64.01 & 66.29 & 65.07 & 64.00 & 63.82 & 65.11 \\
\hline RUP, $\%$ of CP & 35.99 & 33.71 & 34.93 & 36.00 & 36.18 & 34.89 \\
\hline Starch & 23.30 & 19.30 & 15.10 & 32.40 & 31.50 & 29.80 \\
\hline $\mathrm{NFC}^{6} \%$ & 34.16 & 29.72 & 25.71 & 47.53 & 45.64 & 43.69 \\
\hline NDF, $\%$ & 48.08 & 52.43 & 56.75 & 31.72 & 33.88 & 36.05 \\
\hline $\mathrm{ADF}, \%$ & 27.54 & 30.72 & 33.95 & 18.71 & 20.27 & 21.84 \\
\hline $\mathrm{ME},{ }^{7} \mathrm{Mcal} / \mathrm{kg}$ & 2.42 & 2.30 & 2.21 & 2.68 & 2.63 & 2.58 \\
\hline \multicolumn{7}{|l|}{ After casein addition } \\
\hline $\mathrm{CP}, \%$ & 13.89 & 13.18 & 12.70 & 15.38 & 15.09 & 14.78 \\
\hline Solubles, $\%$ of CP & 41.35 & 39.30 & 37.58 & 37.14 & 36.80 & 36.46 \\
\hline $\mathrm{RDP}, \%$ of $\mathrm{CP}$ & 69.18 & 70.61 & 71.23 & 70.17 & 69.62 & 71.18 \\
\hline RUP, $\%$ of $\mathrm{CP}$ & 30.82 & 29.39 & 28.77 & 29.83 & 30.38 & 28.82 \\
\hline $\mathrm{Ca}, \%$ of $\mathrm{DM}$ & 0.76 & 0.72 & 0.78 & 0.57 & 0.61 & 0.65 \\
\hline $\mathrm{P}, \%$ of $\mathrm{DM}$ & 0.33 & 0.37 & 0.37 & 0.30 & 0.27 & 0.29 \\
\hline $\mathrm{Na}, \%$ of $\mathrm{DM}$ & 0.28 & 0.30 & 0.28 & 0.23 & 0.25 & 0.24 \\
\hline $\mathrm{K}, \%$ of $\mathrm{DM}$ & 1.15 & 1.18 & 1.16 & 1.27 & 1.29 & 1.20 \\
\hline $\mathrm{Mg}, \%$ of $\mathrm{DM}$ & 0.25 & 0.28 & 0.27 & 0.26 & 0.24 & $\begin{array}{l}1.20 \\
0.25\end{array}$ \\
\hline
\end{tabular}

${ }^{1}$ Grass hay contained $88.0 \%$ DM, $60.9 \%$ NDF, 35.3\% ADF, $14.1 \%$ CP, and $3.46 \%$ lignin on DM basis.

${ }^{2}$ Corn silage contained $36.5 \%$ DM, 36.7\% NDF, $22.0 \%$ ADF, 9.1\% CP, and $33.1 \%$ starch on DM basis.

${ }^{3}$ Wheat straw contained $92.9 \%$ DM, $78.6 \%$ NDF, $53.2 \%$ ADF, 3.9\% CP, and $8.20 \%$ lignin on DM basis.

${ }^{4}$ Mineral-vitamin mix contained $7.8 \%$ vitamin E, $2.6 \%$ vitamins A, D, and E, $28.6 \%$ distillers corn with soluble vitamin $\mathrm{D}, 14.6 \%$ plain salt, $36.5 \%$ limestone, $2.6 \%$ magnesium oxide, $5.7 \%$ trace mineral premix, and $1.6 \%$ selenium premix on a DM basis.

${ }^{5} \mathrm{n}=6$ composite samples representing 24 samples per treatment taken daily throughout the collection periods of the experiment. All ingredients and nutrients are expressed on a DM basis unless otherwise specified.

${ }^{6}$ Calculated from ingredients as NFC $=100-(\mathrm{NDF}+\mathrm{CP}+$ ether extract + ash $)$.

${ }^{7}$ Estimated as $\mathrm{ME}=\mathrm{TDN} \times 0.04409 \times 0.82$.

freeze-dried urine samples were analyzed for $\mathrm{N}$ on a Costech ECS $4010 \mathrm{C} / \mathrm{N} / \mathrm{S}$ elemental analyzer (Costech Analytical Technologies Inc., Valencia, CA). Urine samples were diluted with distilled water (dilution factor 1:10), and analyzed for uric acid (Cat No. 1045-225, Stanbio Laboratory, Boerne, TX) and allantoin (Chen and Gomes, 1992). Urinary purine derivative (PD; allantoin and uric acid) excretion was used to estimate duodenal flow of microbial protein (Chen and Gomes, 1992). Metabolizable energy intake was calculated for each heifer within each period using observed digestible OM intake $\times 4.409 \times 0.82(\mathrm{NRC}, 2001)$.

\section{Flow Markers}

Solid and liquid fractional passage rates were determined using Co-EDTA (2.5\%; $4 \mathrm{~g}$ of $\mathrm{Co} /$ heifer; 13.87 $\mathrm{g}$ of Co-EDTA in $750 \mathrm{~mL}$ of McDougall's buffer) as a ruminal liquid $\mathrm{kp}$ marker and Cr-mordanted fiber (2.5\%; $3.9 \mathrm{~g}$ of $\mathrm{Cr} /$ heifer; $78 \mathrm{~g}$ of $\mathrm{Cr}$-mordanted fiber) as a solid $\mathrm{kp}$ marker and prepared according to Udén et al. (1980). The Cr-mordanted NDF was composed of a mix of $13 \mathrm{~g}$ of CS, $52 \mathrm{~g}$ of grass hay, and $13 \mathrm{~g}$ of wheat straw for the low-fiber diet; $19.5 \mathrm{~g}$ of CS, $39 \mathrm{~g}$ of grass hay, and $19.5 \mathrm{~g}$ of wheat straw for the medium- 
fiber diet; and $26 \mathrm{~g}$ of CS, $26 \mathrm{~g}$ of grass hay, and 26 $\mathrm{g}$ of wheat straw for the high-fiber diet, representing the proportions that different forages were supplied in the respective diets. Prior to the $0800 \mathrm{~h}$ feeding on $\mathrm{d}$ 11 , approximately $15 \mathrm{~kg}$ of rumen contents were evacuated and markers were completely mixed and returned to the rumen (Hristov et al., 2005). Samples of rumen contents were subsequently obtained from the dorsal, ventral, and caudal areas in the rumen, filtered through 2 layers of cheesecloth, and $50 \mathrm{~mL}$ of fluid and $250 \mathrm{~g}$ of solids were collected at 0 (background), 1, 2, 4, 6, 8, $9,10,12,14,16,20,24$, and $30 \mathrm{~h}$ and analyzed for Co and $\mathrm{Cr}$ concentration in an inductively coupled plasma optical emission spectrometer (PerkinElmer Optima 7300 DV, Billerica, MA).

\section{Blood Sampling}

On d 11, heifers were fitted with a left jugular catheter to allow blood sampling to start $1 \mathrm{~h}$ before feeding on d 12. Blood was collected into 10-mL evacuated serum tubes (SST, Becton Dickinson Vacutainer Systems, Franklin Lakes, NJ) containing clot activator and into evacuated plasma tubes (Becton Dickinson Vacutainer Systems) containing $\mathrm{K}_{3}$ EDTA at the same time points as rumen samples. All tubes were centrifuged at 1,300 $\times g$ at $4^{\circ} \mathrm{C}$ for $10 \mathrm{~min}$ to obtain serum and plasma, which were aliquoted and stored at $-20^{\circ} \mathrm{C}$ until further analysis. Plasma was aspirated and stored at $-20^{\circ} \mathrm{C}$ until analysis for urea-N (procedure no. 0580; Stanbio Laboratory Inc., San Antonio, TX) and glucose (procedure no. 1075; Stanbio Laboratory Inc.).

\section{Ruminal Sampling}

Rumen fluid ( $15 \mathrm{~mL}$ ) was sampled on d 15 to 16 at $0,1,2,4,6,8,9,10,12,14,16,20$, and $24 \mathrm{~h}$ after the $1000 \mathrm{~h}$ feeding to determine the profile of rumen ammonia and VFA as described by Moody et al. (2007). An aliquot of $1 \mathrm{~mL}$ was mixed with $4 \mathrm{~mL}$ of methyl green formalin-saline solution (35\% formaldehyde solution, $100 \mathrm{~mL}$; distilled water, $900 \mathrm{~mL}$; methyl green, $0.6 \mathrm{~g}$; sodium chloride, $8.0 \mathrm{~g}$ ). Mixed samples were stored at $4^{\circ} \mathrm{C}$ and stored in a dark room until counted for ruminal ciliate protozoa using a Fuchs-Rosenthal counting chamber (Hausser Scientific, Horsham, PA) as described by Ogimoto and Imai (1981). At the end of each 16-d period, rumen contents were evacuated 2 $\mathrm{h}$ before and $2 \mathrm{~h}$ after the $1000 \mathrm{~h}$ feeding, which was expected to represent the times rumen contents reach minimum and maximum levels, respectively. Mass and volume of total contents as well as solid and fluid fractions were recorded. The fluid fraction was defined as material not retained on 2 layers of cheesecloth. The proportional composition of the 2 fractions was determined gravimetrically and frozen for later analysis. Samples were freeze-dried and analyzed for chemical composition as indicated previously for feed and fecal samples. Finally, rumen contents were transferred to the next respective heifer following the Latin square design for dietary fiber proportion to minimize adaptation time between periods.

\section{Calculations and Statistical Analysis}

Particulate (forage) and liquid kp (solid and fluid fraction) were determined according to Grovum and Williams (1973). In brief, natural logarithms of the marker concentrations at the different time points were plotted against time, and the slope of the linear portion of the curve was assumed to be the turnover rate of the fluid or solid fraction. The peak point was selected as the starting point for regression analysis, and data points were assessed with or without peak and tail points. The regression with the best coefficient of determination was used $\left(\mathrm{R}^{2}>0.93\right.$ for $\mathrm{Cr}$ and $\mathrm{Co}$; Lykos et al., 1997).

Statistical analyses were conducted in SAS version 9.2 for Windows (SAS Institute, Cary, NC) using the mixed procedure. All dependent variables were analyzed as a split-plot, $3 \times 3$ Latin square design with fixed design effects of period, and fixed treatment effects of F:C; fiber proportion, and their interaction with heifer within F:C included as a random effect. The sequences of fiber proportions were balanced for carryover with respect to previous treatment such that all treatments followed every other treatment once; therefore, fixed effect of the previous treatment also was included in the statistical analysis. The F:C effect was assessed with denominator degrees of freedom and error term associated with whole-plot error of heifer within F:C, and the effects of fiber proportion and the interaction were evaluated against the pooled residual error.

For observations where multiple measures occurred in a period, fixed effect of time and its interaction with other fixed effects were included in the model. Repeated measurements (Littell et al., 1998), including simple, autoregressive one, and compound symmetry covariance structures, were used in the analysis depending on low values received for goodness of fit measures (Akaike's information criterion and Schwartz's Bayesian criterion). Orthogonal polynomials were used to determine the linear and quadratic effects of fiber proportion and their interaction with $\mathrm{F}: \mathrm{C}$, quadratic effects are not presented due to lack of significance. Normality of residuals was evaluated using the Shapiro-Wilk test for normality. Least squares means are presented in tables, and evidence for statistical significance was declared at 
Table 2. Feed intake of dairy heifers fed differing forage-to-concentrate ratios (F:C) as low- (LF) or high-forage (HF) diets containing 3 proportions of fiber through the incorporation of fibrous feedstuffs $(33,50$, or $67 \%$ in the 45 or $90 \%$ forage fraction of the diet)

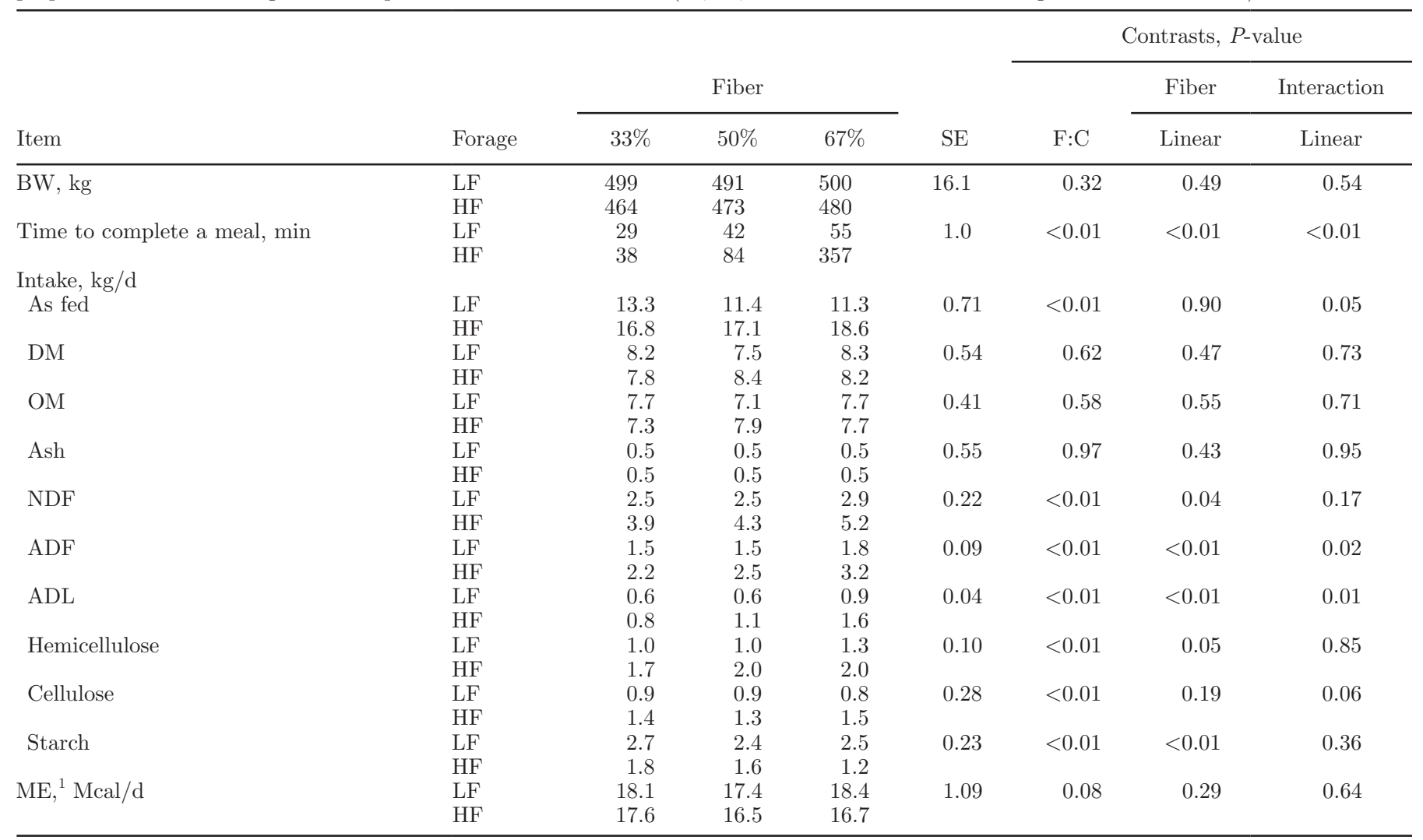

${ }^{1}$ Calculated as digestible $\mathrm{OM} \times 0.82 \times 4.409$.

$P<0.05$ and trends are discussed at $P>0.05$ and $P$ $\leq 0.15$.

\section{RESULTS AND DISCUSSION}

\section{Nutrient Intakes}

Diet ingredient and chemical composition are presented in Table 1. Diets were planned to differ mainly in provision of forage fiber, and NDF concentrations increased linearly in the diets with the addition of HS. Modification of the proportion of CS and HS resulted in 6 different proportions of NDF. Intake of $\mathrm{N}$ was similar among treatments (Table $2 ; 1.82 \mathrm{~g} / \mathrm{kg}$ of $\mathrm{BW}^{0.75}$ ). Heifers were fed diets that provided 18.12 and $17.52 \pm 1.09$ Mcal of ME/d for LF and HF, respectively. Daily DMI was increased with the planned HS incorporation in an attempt to maintain isocaloric diets. Time required to finish a meal (heifers fed $3 \times / \mathrm{d}$ every $8 \mathrm{~h}$ ) was affected by $\mathrm{F}: \mathrm{C}$ and linearly increased as HS was added to the diets, from 29 to $55 \mathrm{~min}$ for the LF-fed heifers and from 38 to 357 min for the HF group. Kitts et al. (2011) reported longer eating time for heifers limit-fed a TMR with $40 \%$ forage when $30 \%$ extra straw was incorpo- rated in the TMR (72 vs. $288 \mathrm{~min} / \mathrm{d}$ ). Actual ADG was greater than expected during the pretrial period, and intakes of DM and $\mathrm{ME}$ were reduced to allow targeted ADG to be accomplished. Heifers fed LF had lower DMI than those fed HF (7.99 vs. $8.15 \pm 0.04 \mathrm{~kg} / \mathrm{d}$ ). Rate of gain $(755 \pm 40.6 \mathrm{~g} / \mathrm{d})$ and ME intake $(0.21 \pm$ $0.05 \mathrm{Mcal} / \mathrm{kg}$ of $\left.\mathrm{BW}^{0.75}\right)$ between the 2 groups were not different $(P=0.46)$.

\section{Diet Digestibility}

Apparent total-tract nutrient digestibility coefficients (dC) are presented in Table 3. Total-tract digestibility of DM, OM, NDF, ADF, and cellulose were lower for $\mathrm{HF}$ diets. Apparent $\mathrm{DM}$ and $\mathrm{OM} \mathrm{dC}$ were similar to results observed by Lascano and Heinrichs (2011) when heifers were fed LF or HF diets composed of a combination of 40 or $80 \%$ CS and corn stover. Digestibility of $\mathrm{NDF}$ and ADF followed a similar pattern as DM and OM apparent digestibility (Zanton and Heinrichs, 2009; Lascano and Heinrichs, 2011). In a limited intake scenario, the $\mathrm{kp}$ of the whole digesta was reduced (Colucci et al., 1990), allowing more time for hemicellulose to be digested evenly within different forage proportions 
as in the present experiment. This allowed cellulose to be retained longer and be further digested in the LF diets. Starch digestibility seems to be increased by higher retention time of LF diets (Lascano and Heinrichs, 2011), as well as by a more numerous amylolytic bacteria population associated with this type of diet (Brown et al., 2006). These results are in agreement with observations in the present study and with the ones reported in limit-fed sheep and cattle (Colucci et al., 1989; Murphy et al., 1994).

Apparent DM, OM, cellulose, and starch dC were reduced linearly as HS increased from 33.3 to $66.6 \%$ in the forage fraction of diets. Increasing HS resulted in increased proportions of NDF that modulated the response in OM digestibility (Firkins et al., 2001). In agreement with Lascano and Heinrichs (2011), OM dC was different between $\mathrm{F}: \mathrm{C}$ diets, and increased dietary $\mathrm{NDF}$ concentration caused a greater reduction in $\mathrm{OM}$ digestibility in $\mathrm{HF}$ diets. It has been observed that $\mathrm{OM}$ and $\mathrm{DM} \mathrm{dC}$ were reduced when low-quality wheat straw or corn stover replaced concentrates in midlactation cow or heifer diets, respectively (Halevi et al., 1973; Lascano and Heinrichs, 2011). Replacing CS with HS within the same $\mathrm{F}$ :C resulted in similar hemicellulose concentration in the diet, but cellulose and lignin (ADF) concentrations were higher, resulting in reduced $\mathrm{OM}$ and $\mathrm{DM} \mathrm{dC}$ due to lower digestibility of cellulose (Table 3); similar results were observed by Keys and Smith (1981). Starch apparent dC was also reduced when additional corn stover replaced CS in diets precision-fed to dairy heifers (Lascano and Heinrichs, 2011). Results from that experiment suggested that NDF concentration in the diet increases $\mathrm{kp}$ of grain, accelerating the passage of ruminally unfermented starch and that intestinal digestion of starch may be limited (Galyean and Defoor, 2003), reducing total-tract digestibility.

Apparent $\mathrm{N}$ dC was not different between $\mathrm{F}$ : C treatments or with increasing HS in treatments, in agreement with a similar study where corn stover replaced CS as HS replaced CS in the present experiment (Lascano

Table 3. Nutrient digestibility in dairy heifers fed differing forage-to-concentrate ratios (F:C) as low- (LF) or high-forage (HF) diets containing 3 proportions of fiber through the incorporation of fibrous feedstuffs $(33,50$, or $67 \%$ in the 45 or $90 \%$ forage fraction of the diet)

\begin{tabular}{|c|c|c|c|c|c|c|c|c|}
\hline \multirow{2}{*}{ Digestibility \% } & \multirow{2}{*}{ Forage } & \multirow{2}{*}{\multicolumn{3}{|c|}{ Fiber }} & \multirow{2}{*}{$\mathrm{SE}$} & \multicolumn{3}{|c|}{ Contrasts, $P$-value } \\
\hline & & & & & & & Fiber & Interaction \\
\hline \multirow[t]{2}{*}{$\mathrm{DM}$} & $\mathrm{LF}$ & 71.0 & 68.1 & 66.3 & 2.06 & $<0.01$ & 0.04 & 0.92 \\
\hline & $\mathrm{HF}$ & 63.5 & 57.9 & 58.3 & & & & \\
\hline $\mathrm{OM}$ & $\mathrm{LF}$ & 72.2 & 69.4 & 67.7 & 2.11 & $<0.01$ & 0.05 & 0.92 \\
\hline $\mathrm{NDF}$ & $\mathrm{HF}$ & 54.6 & 51.4 & 50.7 & & & & \\
\hline \multirow{2}{*}{$\mathrm{ADF}$} & LF & 48.3 & 59.2 & 53.6 & 5.83 & $<0.01$ & 0.52 & 0.20 \\
\hline & $\mathrm{HF}$ & 47.8 & 26.9 & 35.5 & & & & \\
\hline \multirow{2}{*}{ Cellulose $^{1}$} & $\mathrm{LF}$ & 76.5 & 66.6 & 54.3 & 6.53 & 0.06 & 0.03 & 0.53 \\
\hline & $\mathrm{HF}$ & 70.9 & 68.8 & 57.8 & & & & \\
\hline \multirow[t]{2}{*}{ Hemicellulose $^{2}$} & LF & 62.9 & 50.1 & 40.3 & 13.45 & 0.67 & 0.94 & 0.26 \\
\hline & $\mathrm{HF}$ & 44.9 & 55.3 & 69.5 & & & & \\
\hline \multirow[t]{2}{*}{ Digestibility } & LF & 69.3 & 64.1 & 64.6 & 5.98 & 0.28 & 0.28 & 0.90 \\
\hline & HF & 73.1 & 69.0 & 67.5 & & & & \\
\hline \multirow[t]{2}{*}{ Intake } & $\mathrm{LF}$ & 182.3 & 176.8 & 188.1 & 8.35 & 0.06 & 0.59 & 0.58 \\
\hline & $\mathrm{HF}$ & 188.9 & 190.5 & 191.4 & & & & \\
\hline \multirow[t]{2}{*}{ Fecal N, g/d } & $\mathrm{LF}$ & 55.0 & 61.6 & 64.3 & 10.76 & 0.72 & 0.44 & 1.00 \\
\hline & $\mathrm{HF}$ & 49.6 & 59.1 & 61.8 & & & & \\
\hline \multirow[t]{2}{*}{ Urine $\mathrm{N}, \mathrm{g} / \mathrm{d}$} & LF & 58.7 & 70.2 & 77.5 & 11.74 & 0.11 & 0.04 & 0.64 \\
\hline & $\mathrm{HF}$ & 85.5 & 94.9 & 101.6 & & & & \\
\hline \multirow{2}{*}{ Total excreted N, g/d } & $\mathrm{LF}$ & 113.2 & 131.2 & 142.2 & 11.57 & 0.21 & 0.04 & 0.27 \\
\hline & $\mathrm{HF}$ & 135.4 & 154.9 & 163.4 & & & & \\
\hline \multirow[t]{2}{*}{ Retained N, g/d } & $\mathrm{LF}$ & 69.4 & 45.9 & 44.9 & 10.85 & $<0.01$ & 0.12 & 0.57 \\
\hline & $\mathrm{HF}$ & 53.3 & 34.6 & 28.4 & & & & \\
\hline Retained N, \% intake & $\mathrm{LF}$ & 38.3 & 25.5 & 24.8 & 6.14 & $<0.01$ & 0.11 & 0.56 \\
\hline
\end{tabular}

${ }^{1}$ Cellulose $=\mathrm{ADF}-\mathrm{ADL}$

${ }^{2}$ Hemicellulose $=$ NDF - ADF. 
Table 4. Excretion parameters of dairy heifers fed differing forage-to-concentrate ratios (F:C) as low- (LF) or high-forage (HF) diets containing 3 proportions of fiber through the incorporation of fibrous feedstuffs $(33,50$, or $67 \%$ in the 45 or $90 \%$ forage fraction of the diet)

\begin{tabular}{|c|c|c|c|c|c|c|c|c|}
\hline Item, $\mathrm{kg} / \mathrm{d}$ & Forage & \multicolumn{3}{|c|}{ Fiber } & $\mathrm{SE}$ & \multicolumn{3}{|c|}{ Contrasts, $P$-value } \\
\hline \multirow[t]{2}{*}{ Wet feces } & $\mathrm{LF}$ & 11.6 & 14.7 & 17.9 & \multirow[t]{2}{*}{0.96} & \multirow[t]{2}{*}{$<0.01$} & \multirow[t]{2}{*}{0.02} & \multirow[t]{2}{*}{0.10} \\
\hline & $\mathrm{HF}$ & 19.4 & 25.4 & 23.1 & & & & \\
\hline Dry feces & $\mathrm{LF}$ & 2.3 & 2.4 & 2.7 & 0.23 & $<0.01$ & 0.06 & 0.70 \\
\hline Fecal water ${ }^{1}$ & $\mathrm{HF}$ & 16.7 & 22.1 & 19.6 & 0.83 & $<0.01$ & $<0.01$ & 0.03 \\
\hline \multirow[t]{2}{*}{ Urine } & $\mathrm{LF}$ & 12.6 & 10.2 & 6.3 & \multirow[t]{2}{*}{1.06} & \multirow[t]{2}{*}{0.17} & \multirow[t]{2}{*}{0.01} & \multirow[t]{2}{*}{0.04} \\
\hline & $\mathrm{HF}$ & 8.8 & 8.4 & 8.1 & & & & \\
\hline \multirow[t]{2}{*}{ Total water excreted } & $\mathrm{LF}$ & 22.4 & 21.1 & 22.3 & \multirow[t]{2}{*}{1.30} & \multirow[t]{2}{*}{0.01} & \multirow[t]{2}{*}{0.48} & \multirow[t]{2}{*}{0.53} \\
\hline & $\mathrm{HF}$ & 25.3 & 30.1 & 27.1 & & & & \\
\hline
\end{tabular}

${ }^{1}$ Weight lost on drying at $55^{\circ} \mathrm{C}$.

and Heinrichs, 2011). Urine N was numerically higher for $\mathrm{LF}$, resulting in a significantly higher $\mathrm{N}$ retention for this group (Table 3). There was a linear increase of $\mathrm{N}$ excreted in urine in both diets as HS increased proportionally in diets. It has been reported that increasing NDF-to-starch ratios (from 0.74 to 1.27 ) favors $\mathrm{N}$ retention in lactating cows fed LF diets (Beckman and Weiss, 2005). However, an opposite linear effect was observed under precision-feeding conditions in the present experiment when NDF proportions ranged from 32 to $56 \% \mathrm{DM}$ and NDF-to-starch ratio (from 0.97 to 3.76 ); this highlights the importance of the interaction between protein and carbohydrate ruminal degradability.

\section{Nutrient Excretion}

Environmental excretion data are presented in Table 4. Wet fecal, dry fecal, and fecal water outputs were lower for LF in comparison with HF diets. This is in agreement with previous results when dairy heifers were precision-fed different $\mathrm{F}$ :C diets. Wet fecal output for LF heifers represented $66 \%$ of what was excreted from their HF counterparts, agreeing with previous results (Zanton and Heinrichs, 2009; Lascano and Heinrichs, 2011). Enhanced DM and OM digestibility in LF diets are responsible for the observed results related to fecal output. Urine output was not different between different F:C; urine output has been increased in LFfed heifers only when higher proportions of concentrate were fed to dairy heifers (75 and $80 \%$ respectively; Zanton and Heinrichs, 2009; Lascano and Heinrichs, 2011). Other experiments have failed to observe differences in urine output among LF or HF diets similar to what was observed in the present experiment, these experiments fed lower concentrate proportions (67 and $60 \%$, respectively; Moody et al., 2007; Lascano et al., 2009b) than the previously mentioned studies (Zanton and Heinrichs, 2009; Lascano and Heinrichs, 2011) but still higher than in the present study (10 and 55\%, respectively).

We noted linear increase in wet and dry fecal output as well as fecal water as HS increased in the rations. These results are consistent with the linear reduction observed in DM and $\mathrm{OM}$ digestibility, reflect lower digestibility of HS, and are in agreement with results reported in a previous experiment in which corn stover was used to incrementally replace CS in precision-fed heifers (Lascano and Heinrichs, 2011). Urine output decreased linearly and followed the same trend for dietary F:C. These results confirm the conclusion from other experiments that dietary NDF concentrations are modulating water balance in the heifer (Zanton and Heinrichs, 2009; Lascano and Heinrichs, 2011).

\section{Water Intake}

Water intake and dynamics are presented in Table 5 . We found no differences in water intake or total water intake (voluntary + feed water) between $\mathrm{F}: \mathrm{C}$ groups. No difference in total water consumed per kilogram of DMI was observed, but more total water per kilogram of NDF intake tended $(P=0.06)$ to be consumed by LF-fed heifers, confirming previous results (Lascano and Heinrichs, 2011). The percentage of fecal water relative to total water consumed was lower for LF diets (38.13 vs. 50.71\%) and the opposite was observed for urine (33.30 vs. $22.66 \%$ ), but total percentage of water excreted was similar between F:C groups and represented approximately $72 \%$. Thus, the sensible (sweat, saliva, panting) and insensible (respiratory and sweat diffusion) water losses were $28 \%$, which are 4 and 12 percentage units higher than what was reported with younger and smaller dairy heifers [362 \pm 8 and $335 \pm$ $7 \mathrm{~kg}$ from Zanton and Heinrichs (2009) and Lascano 
Table 5. Water intake and proportion excreted of dairy heifers fed differing forage-to-concentrate ratios (F:C) as low- (LF) or high-forage (HF) diets containing 3 proportions of fiber through the incorporation of fibrous feedstuffs $(33,50$, or $67 \%$ in the 45 or $90 \%$ forage fraction of the diet)

\begin{tabular}{|c|c|c|c|c|c|c|c|c|}
\hline \multirow{2}{*}{ Item } & \multirow{2}{*}{ Forage } & \multirow{2}{*}{\multicolumn{3}{|c|}{ Fiber }} & \multirow{2}{*}{$\mathrm{SE}$} & \multicolumn{3}{|c|}{ Contrasts, $P$-value } \\
\hline & & & & & & $\mathrm{F}: \mathrm{C}$ & $\frac{\text { Fiber }}{\text { Linear }}$ & $\frac{\text { Interaction }}{\text { Linear }}$ \\
\hline \multicolumn{9}{|l|}{ Water intake, $\mathrm{L} / \mathrm{d}$} \\
\hline \multirow[t]{2}{*}{ Voluntary } & LF & 31.0 & 22.4 & 26.8 & 4.04 & 0.92 & 0.72 & 0.48 \\
\hline & $\mathrm{HF}$ & 26.9 & 28.3 & 27.3 & & & & \\
\hline \multirow[t]{2}{*}{ Total/kg of DMI } & LF & 4.4 & 3.5 & 3.7 & 0.46 & 0.49 & 0.45 & 0.43 \\
\hline & $\mathrm{HF}$ & 4.1 & 4.4 & 4.1 & & & & \\
\hline \multirow[t]{2}{*}{ Total/kg of NDF } & $\mathrm{LF}$ & 14.2 & 10.3 & 9.9 & 1.43 & 0.06 & 0.13 & 0.22 \\
\hline & $\mathrm{HF}$ & 8.5 & 8.3 & 8.0 & & & & \\
\hline \multicolumn{9}{|c|}{ Water excreted per consumed, ${ }^{2} \%$} \\
\hline \multirow[t]{2}{*}{ Feces } & LF & 30.1 & 40.4 & 43.9 & 3.70 & 0.04 & 0.03 & 0.11 \\
\hline & $\mathrm{HF}$ & 49.4 & 50.4 & 52.3 & & & & \\
\hline
\end{tabular}

${ }^{1}$ Total water intake $=$ voluntary water intake + feed water.

${ }^{2}$ Consumption is total water intake and excretion includes fecal water calculated as weight lost on drying at $55^{\circ} \mathrm{C}$ and total weight of urine output.

and Heinrichs (2011), respectively] housed in similar environments.

\section{Microbial Protein}

Microbial protein flow to the duodenum is presented in Table 6. No differences were detected for allantoin, total PD, or microbial CP between $\mathrm{F}$ : $\mathrm{C}$ treatments. It has been suggested that LF diets in cows decreased flow of microbial protein to the duodenum because of a decrease in liquid, bacteria, and small particle turnover rates as well as lower ruminal pH (Hungate, 1966; Owens and Isaacson, 1977). In agreement with these observations, Lascano and Heinrichs (2009) reported lower rumen turnover rates as F:C decreased from 80:20 to $40: 60$ in control-fed heifers ( 88 to $78 \%$, respectively) and when comparing LF to HF diets (Lascano and Heinrichs, 2011). It has also been reported that decreasing F:C increases microbial protein yield (Lascano et al., 2009a; Pina et al., 2009); it is important to notice that these experiments decreased the F:C from 80:20 to $60: 40$ and from 80:20 to 40:60 in the diet, respectively. This is in agreement with results from the present experiment, where LF diet had greater predicted microbial protein (544.64 vs. $371.22 \mathrm{~g} / \mathrm{d}$ ); however, in as HS increased in LF, microbial protein was reduced. It has also been shown that beyond these proportions ( $>60 \%$ concentrate) microbial protein decreases with additional concentrate incorporation in the diet as a consequence of excess carbohydrate that is not degraded in the rumen (Lascano and Heinrichs, 2011). Valadares et al. (1999) reported a quadratic effect in dairy cows fed $20,35,50$, and $65 \%$ concentrate with the highest microbial protein for the $50 \%$ concentrate diet concurrent with the higher microbial protein flow observed in the present experiment for the LF (45\% concentrate). They concluded that $35 \%$ NFC is adequate to improve microbial protein synthesis because highly fermentable carbohydrates are more effective than structural carbohydrates in promoting microbial growth (Hoover and Stokes, 1991).

We noted a significant linear decrease in microbial protein as HS increased in both $\mathrm{F}$ :C treatments as a consequence of the linear reduction of PD used to calculate this parameter. In a previous experiment where fiber concentration was increased in LF and HF through inclusion of corn stover and precision-fed to dairy heifers, microbial protein increased quadratically in LF whereas we noted a quadratic decrease in HF group (Lascano and Heinrichs, 2011). Important differences to highlight between these 2 experiments are that F:C in Lascano and Heinrichs (2011) was 20:80 and 80:20 for LF and HF, respectively, compared with 45:55 and 90:10, respectively, in the present study, and the increment of corn stover was from 0 to $60 \%$ of the forage fraction whereas in the present experiment HS went from 33 to $67 \%$.

When a high proportion of concentrates was used in LF diets $(>80 \%)$, microbial protein was reported to be lower than in HF, but incremental corn stover addition enhanced predicted microbial protein flow to the duodenum and the opposite happened in the HF group (Lascano and Heinrichs, 2011). When sources of coarse forage have been added to LF diets, an increase 
Table 6. Daily urinary excretion of purine derivatives (PD), estimated microbial CP flow, and total protozoa counts of dairy heifers fed differing forage-to-concentrate ratios (F:C) as low- (LF) or high-forage (HF) diets containing 3 proportions of fiber through the incorporation of fibrous feedstuffs $(33,50$, or $67 \%$ in the 45 or $90 \%$ forage fraction of the diet)

\begin{tabular}{|c|c|c|c|c|c|c|c|c|}
\hline Item & Forage & \multicolumn{3}{|c|}{ Fiber } & $\mathrm{SE}$ & \multicolumn{3}{|c|}{ Contrasts, $P$-value } \\
\hline \multirow[t]{2}{*}{ Allantoin, mmol } & $\mathrm{LF}$ & 128.8 & 85.8 & 63.6 & \multirow[t]{2}{*}{15.19} & 0.85 & 0.04 & \multirow[t]{2}{*}{0.12} \\
\hline & $\mathrm{HF}$ & 96.3 & 85.7 & 89.5 & & & & \\
\hline Uric acid, mmol & $\mathrm{LF}$ & 14.1 & 8.9 & 7.7 & 2.32 & 0.47 & 0.06 & 0.54 \\
\hline Total PD, mmol & $\mathrm{HF}$ & 107.8 & 94.7 & 98.0 & 16.88 & 0.83 & & 0.13 \\
\hline \multirow[t]{2}{*}{ Allantoin, \% PD } & $\mathrm{LF}$ & 90.0 & 90.2 & 90.3 & \multirow[t]{2}{*}{1.65} & \multirow[t]{2}{*}{0.56} & 0.40 & \multirow{2}{*}{0.62} \\
\hline & $\mathrm{HF}$ & 89.4 & 91.2 & 91.7 & & & & \\
\hline \multirow[t]{2}{*}{ Microbial $\mathrm{CP},{ }^{1} \mathrm{~g} / \mathrm{d}$} & $\mathrm{LF}$ & 544.6 & 307.7 & 165.2 & \multirow[t]{2}{*}{87.31} & \multirow[t]{2}{*}{0.87} & 0.03 & \multirow[t]{2}{*}{0.14} \\
\hline & $\mathrm{HF}$ & 371.2 & 304.0 & 307.2 & & & & \\
\hline \multirow[t]{2}{*}{ Protozoa, $10^{3} / \mathrm{mL}$} & LF & 296.1 & 217.5 & 201.3 & \multirow[t]{2}{*}{25.45} & \multirow[t]{2}{*}{0.11} & 0.23 & \multirow[t]{2}{*}{0.02} \\
\hline & $\mathrm{HF}$ & 169.5 & 238.8 & 201.1 & & & & \\
\hline
\end{tabular}

${ }^{1}$ Estimated according to the methods and equations of Chen and Gomes (1992).

in salivation rate, which provides a ruminal $\mathrm{pH}$ appropriate for a broader range of bacteria types (Hungate, 1966), results in more microbial protein synthesis and flow to the duodenum (Owens and Isaacson, 1977). However, in the present experiment as HS, a coarse forage source was added to the rations a linear decrease in microbial protein flow to the duodenum was observed, and this decrease was more pronounced in the LF-fed group ( $45 \%$ forage). This effect is similar to what was observed in the HF diet ( $80 \%$ forage) for Lascano and Heinrichs (2011), where a lower predicted microbial protein was observed. This can be attributed to the reduced availability of readily fermentable carbohydrates as more structural carbohydrates are incorporated into the diets. Thus, incorporation of dietary fiber in rations where $\mathrm{F}: \mathrm{C}$ are low is instrumental to increase microbial protein synthesis, and as $\mathrm{F}: \mathrm{C}$ increases additional dietary fiber reduces microbial protein synthesis and $\mathrm{N}$ utilization. Therefore, inclusion of coarse forage, such as corn stover or HS, in LF diets ( $<20 \%$ forage) seems to be beneficial to microbial protein synthesis but detrimental in LF or $\mathrm{HF}$ ( $>45 \%$ forage) where $\mathrm{NDF}$ proportions are intrinsically high.

Mean protozoa numbers were not different between treatments, possibly due to large variability between samples (Table 6). Higher numbers of protozoa have been reported for diets having greater proportions of degradable carbohydrates up to a certain point after which the number starts to decline (Dehority and Orpin, 1988), as in the case of the LF diet in this experiment. Protozoa numbers have been correlated with the ratio of acetate to propionate $(\mathbf{A}: \mathbf{P})$; high A:P increased protozoa numbers whereas diets that have a reduced A:P resulted in lower protozoa count (Brossard et al.,
2006), which is consistent with the linear decrease in $\mathrm{A}: \mathrm{P}$ as HS replaced CS in the present experiment.

\section{Ruminal Fermentation}

The VFA profile of rumen samples are presented in Table 7 . The LF-fed heifers had a greater ruminal VFA concentration $(P=0.03)$, which was maintained throughout the day (Figure 1). Butyrate molar proportion tended to be higher in LF $(P=0.08)$ compared with HF, but LF diets exhibited lower acetate (67.1 vs. $64.1 \mathrm{~mol} / 100 \mathrm{~mol} ; P \leq 0.01)$ and valerate proportions, and a tendency for lower A:P (3.9 vs. $4.2 ; P=$ 0.09). No differences between LF and HF were observed in propionate (17.1 vs. $16.6 \mathrm{~mol} / 100 \mathrm{~mol} ; P=0.20$ ), isobutyrate, or isovalerate molar proportions.

It has been reported that VFA concentrations were higher in LF diets when compared with HF (134 vs. $119 \mathrm{mM}$ ) diets in dual-flow fermenters when $\mathrm{pH}$ was maintained at 6.4 (Fuentes et al., 2009). These concentrations are similar to the ones observed in the present experiment (133 vs. $122 \mathrm{mM}$ for LF and HF diets respectively; Figure 1) due to a consistently but not significantly lower $\mathrm{pH}$ for the LF (6.3 vs. 6.5) diets (Figure 2). Calsamiglia et al. (2008) concluded that interaction between $\mathrm{pH}$ and $\mathrm{F}: \mathrm{C}$ in the diet is the main factor influencing ruminal VFA concentration, with $\mathrm{pH}$ having a greater contribution when F:C are modified. To complement this observation, VFA concentration was not different across the $\mathrm{F}: \mathrm{C}$ treatments when $\mathrm{pH}$ was not altered in heifers precision-fed $\mathrm{F}$ :C of 80:20, 60:40, and 40:60 (Lascano and Heinrichs, 2009). Thus, when $\mathrm{pH}$ has been affected by F:C, VFA concentrations have been observed to be higher in LF in comparison 
to HF (Moody et al., 2007); this is similar to what was observed in the present experiment, in which rumen $\mathrm{pH}$ was decreased as the amount of concentrate incorporated in the diet increased, which is consistent with greater fermentability of components in LF compared with HF diets.

Acetate molar proportion was lower in LF diets consistent with other reports using LF diets for precision fed-dairy heifers (Moody et al., 2007; Lascano and Heinrichs, 2009) and steers (Bourquin et al., 1994). Butyrate molar proportion tended to be higher for LF ( $P$ $=0.08$ ), similar to results reported in vitro by Fuentes et al. (2009) when $\mathrm{pH}$ was held constant at 6.4 , which is similar to the $\mathrm{pH}$ observed in the present experiment. In some experiments butyrate and propionate proportions increase at the expense of acetate (Carro et al., 2000), but in others this happened at the expense of acetate and propionate (Brossard et al., 2003). In the present experiment butyrate proportion increased at the expense of acetate because propionate did not change among $\mathrm{F}: \mathrm{C}$ treatments. When changing the $\mathrm{F}: \mathrm{C}$ ratio, butyrate proportions seem to increase in diets when average $\mathrm{pH}$ is $>6.2$ (present experiment, Fuentes et al., 2009; Ramos et al., 2009) but are not affected when $\mathrm{pH}$ is $<6.0$ (Carro et al., 2000; Lascano and Heinrichs, 2009).

Changes in A:P show a difference in the nature of rumen fermentation when increasing proportions of HS were fed. This suggests that a shift in microbial population occurred with HS increments in the diets (Tajima et al., 2001; Lascano and Heinrichs, 2009). No difference in butyrate was observed with HS increments in any $\mathrm{F}: \mathrm{C}$ treatments, in agreement with Ramos et al. (2009), where fiber content increased from 42 to $50 \%$ NDF by replacing alfalfa hay with grass hay. Valerate molar proportion was greater for LF diets. Valerate production in the rumen comes partially from AA fermentation and partially from carbohydrates. It has been suggested that decreases in valerate can be due to an increased liquid fraction passage rate for HF (Eun et al., 2004), resulting in a reduction of retention time of fermentable carbohydrates (Fuentes et al., 2009). This is in agreement with Coe et al. (1999), who observed higher valerate molar proportion as steers received

Table 7. Rumen fermentation and blood metabolites of dairy heifers fed differing forage-to-concentrate ratios (F:C) as low- (LF) or high-forage (HF) diets containing 3 proportions of fiber through the incorporation of fibrous feedstuffs $(33,50$, or $67 \%$ in the 45 or $90 \%$ forage fraction of the diet)

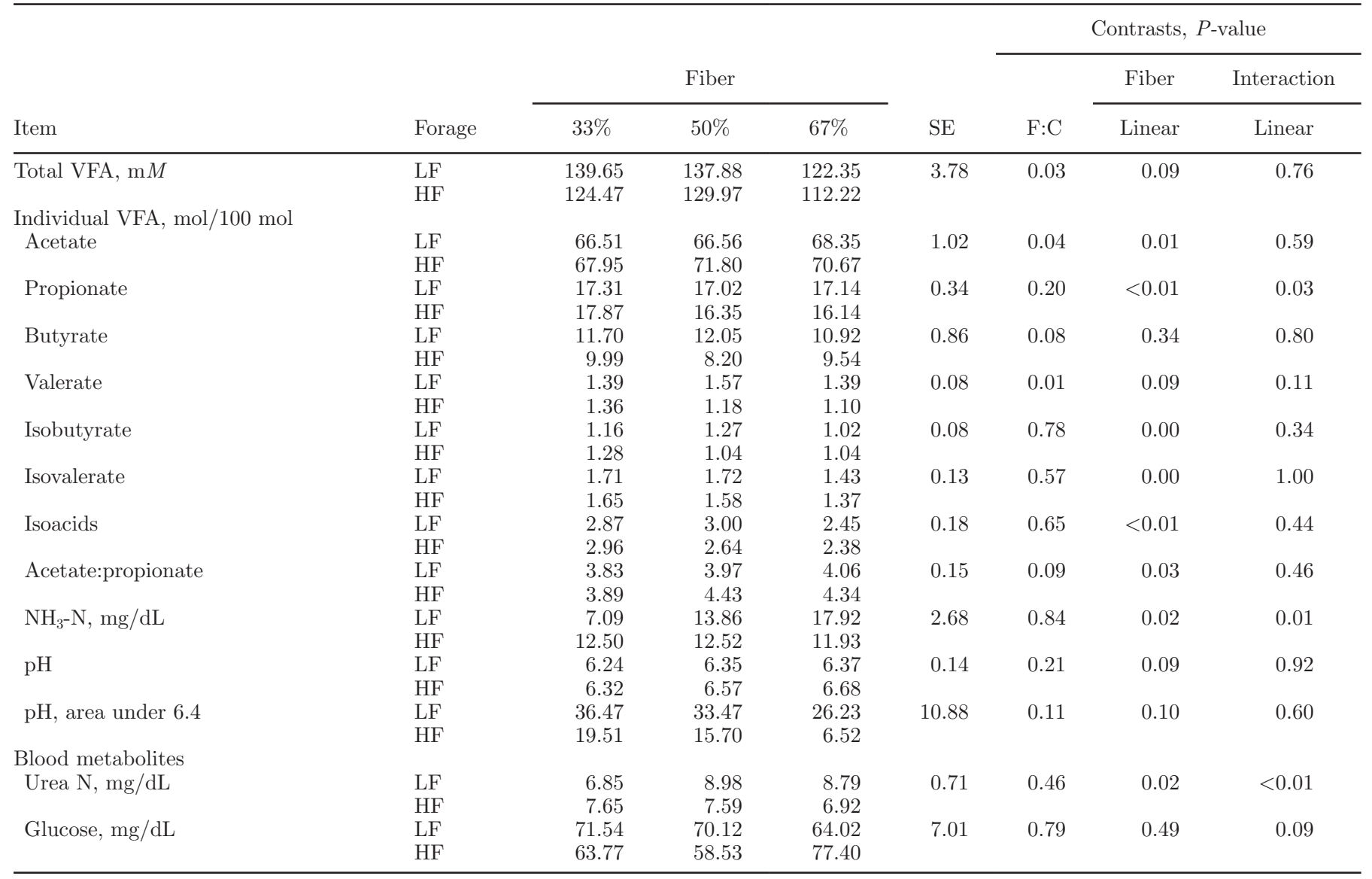


a diet with increasing proportion of concentrate. Increased feed efficiency has been related to steers with higher butyrate and valerate concentration (Guan et al., 2008), which has been attributed to enhanced VFA absorption due to efficiency of rumen epithelial cells using these VFA (Penner et al., 2009). Isoacid molar proportions were not different among $\mathrm{F}$ : $\mathrm{C}$ treatments. In the present experiment, as $\mathrm{NH}_{3}-\mathrm{N}$ concentrations were high throughout the day (Figure 3), no deamination was necessary, explaining the lack of differences between $\mathrm{F}$ :C treatments.
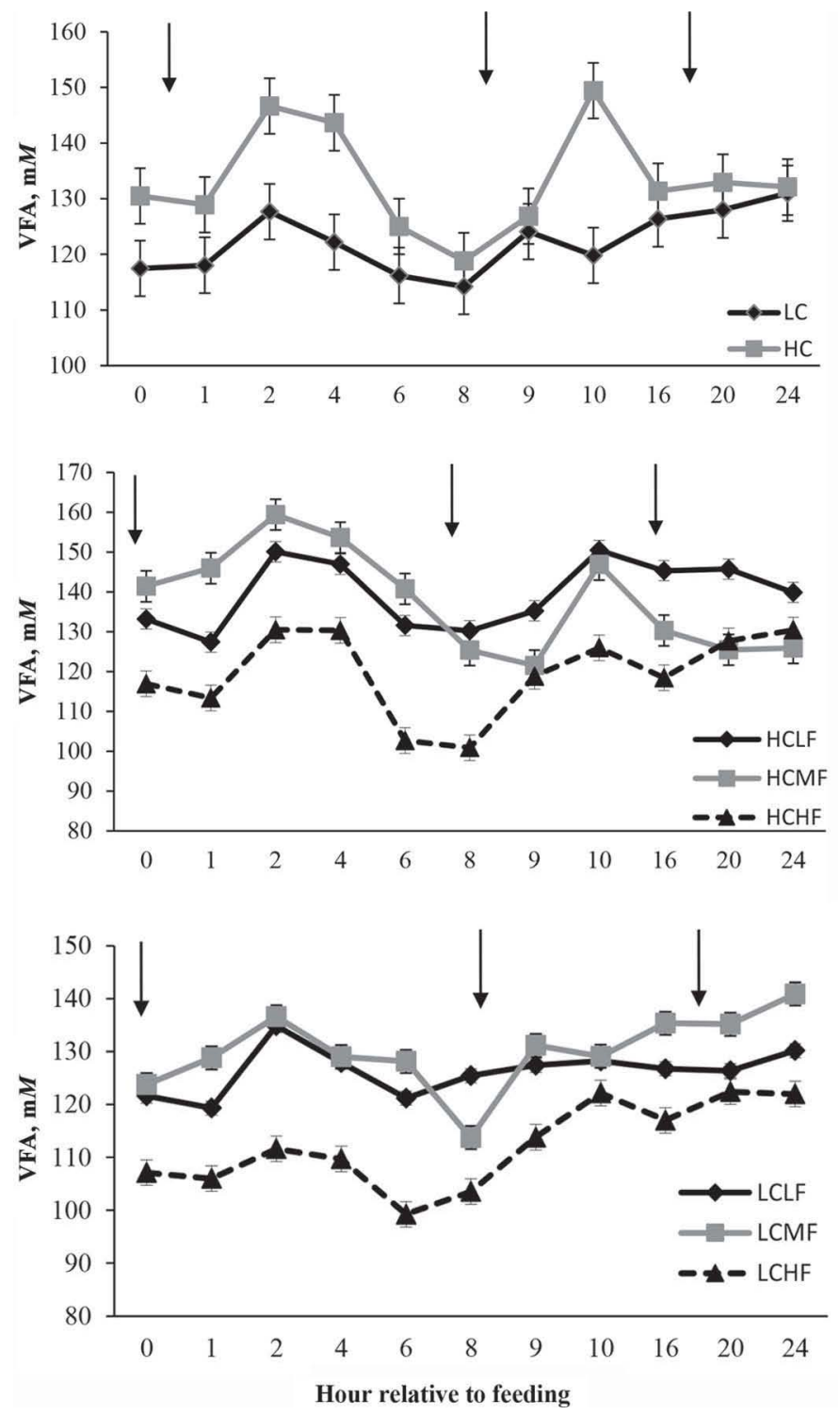

Figure 1. Diurnal VFA concentration of dairy heifers fed differing forage-to-concentrate ratios $(\mathrm{F}: \mathrm{C})$ as low- (LC) or high-concentrate (HC) diets containing 3 proportions of fiber through the incorporation of fibrous feedstuffs $[33 \%$, low fiber (LF), $50 \%$, medium fiber (MF), or $67 \%$, high fiber (HF) in the 45 or $90 \%$ forage fraction of the diet]. Arrows represent feeding times.
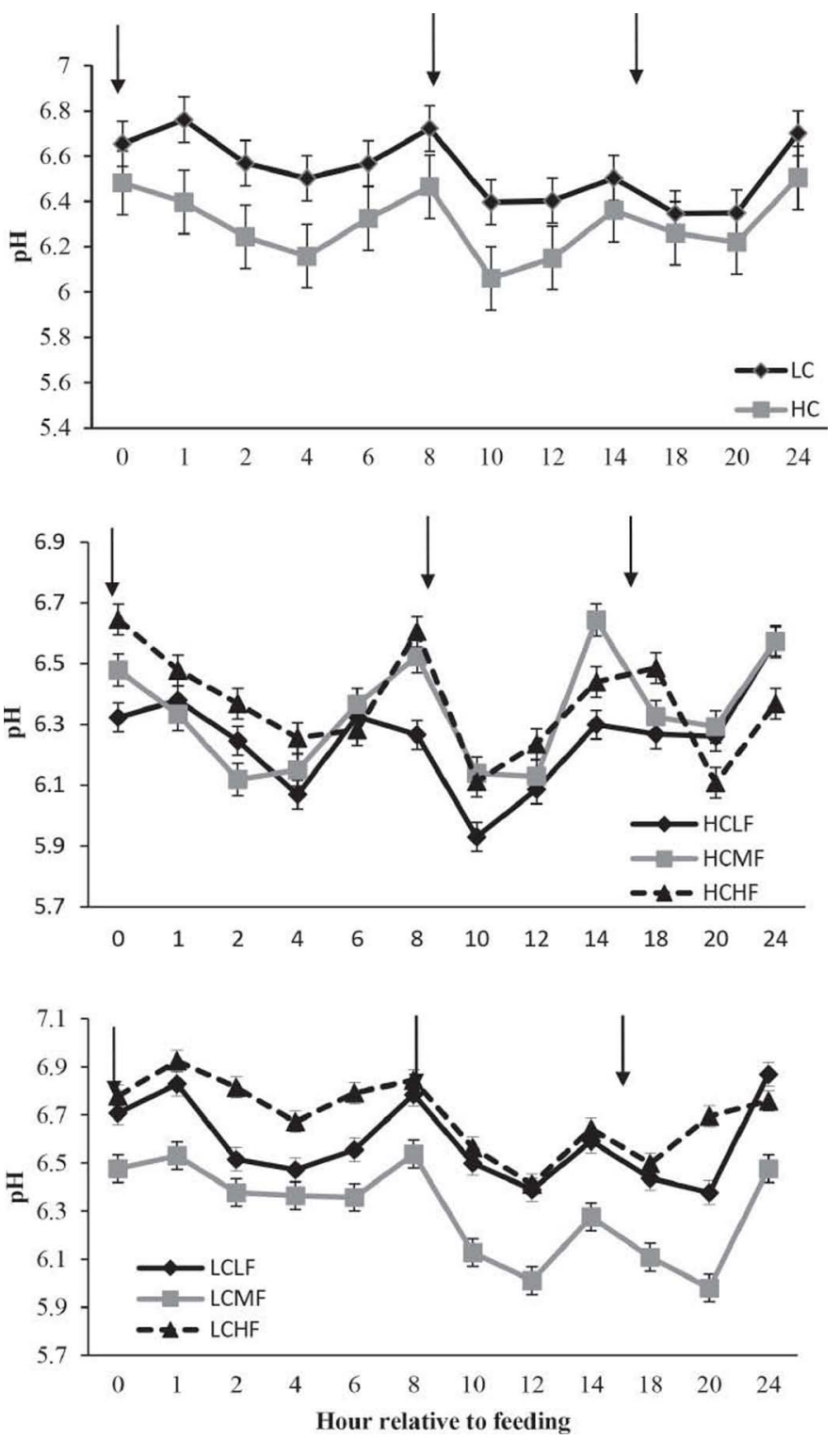

Figure 2. Diurnal pH of dairy heifers fed differing forage-to-concentrate ratios (F:C) as low- (LC) or high-concentrate (HC) diets containing 3 proportions of fiber through the incorporation of fibrous feedstuffs $[33 \%$, low fiber (LF), $50 \%$, medium fiber (MF), or $67 \%$, high fiber (HF) in the 45 or $90 \%$ forage fraction of the diet]. Arrows represent feeding times.

It seems that the linear decrease in valerate molar proportion as HS was incorporated in the rations was mainly due to a numerically increased fluid fraction $(P$ $=0.14)$ passage rate as dietary fiber increased in the ration (Table 7). Interestingly, the decrease in ruminal concentration of valerate corresponds quite closely to the increased liquid fraction turnover rate as dietary fiber increased in the diets of precision-fed dairy heifers. This corroborates previous observations regarding interactions between valerate, fluid passage rate, and 
reduced retention time of fermentable carbohydrates (Meng et al., 1999; Eun et al., 2004).

We observed a linear tendency to decrease total VFA concentration $(P=0.10)$ and valerate molar proportion $(P=0.09)$ and a significant linear reduction in acetate, isobutyrate, isovalerate, and isoacids; whereas there was a linear increase in propionate molar proportions and $\mathrm{A}: \mathrm{P}$ as HS increased in the rations (Table 7). The linear decrease in total VFA is a response to the lower fermentability and digestibility of the HS combination in comparison to CS (Figure 1), and is consistent with the linear reduction observed in DM and OM digestion.

Isoacids decreased linearly as HS was incorporated in diets. This can be explained because of the increase in cellulolytic bacteria that need to incorporate these isoacids for their growth and fiber digestion, causing depletion in the rumen (Yang, 2002). Furthermore, sodium caseinate (contains mainly AA and peptides) cannot be directly incorporated into microbial protein, and the presence of isoacids is necessary (Eun et al., 2004). In scenarios where RDP exceeds that used for microbial protein synthesis, AA and peptides can be used as ATP-yielding substrates to sustain growth of rumen microorganisms (Russell et al., 1983). This explains the linear increase in accumulation of ruminal $\mathrm{NH}_{3}-\mathrm{N}$ and the incorporation of isoacids as carbon skeletons resulting in the reduction observed in the molar proportion of isoacids in the present experiment.

Mean ruminal $\mathrm{NH}_{3}-\mathrm{N}$ concentration was not different among $\mathrm{F}: \mathrm{C}(P=0.84)$. An $\mathrm{LF}$ diet has elicited low $\mathrm{NH}_{3}-\mathrm{N}$ in dual-flow fermenters when comparing diets with 10:90 or 60:40 F:C (Calsamiglia et al., 2008). This was observed when comparing LF to HF diet with no HS supplementation ( 7.09 vs. $12.50 \mathrm{mg} / \mathrm{dL})$, but because both treatments had incremental HS addition main effects of $\mathrm{F}$ : $\mathrm{C}$ were not detectable. Lower $\mathrm{NH}_{3}-\mathrm{N}$ concentration in LF diets favors ammonia utilization for de novo synthesis of AA by incorporation in bacterial protein and results in higher NAN (Fuentes et al., 2009).

A greater availability of readily degradable carbohydrates in the rumen favors $\mathrm{NH}_{3}-\mathrm{N}$ utilization as well as a reduction in protein hydrolysis and deamination by ruminal microorganisms, with a respective increase in bacteria numbers (Lascano and Heinrichs, 2009). This explains the more pronounced linear decrease in predicted microbial protein synthesis and BUN concentrations for LF diets and the lack of significant changes in the HF treatment. In the present experiment sodium caseinate was added to diets at $0.28 \mathrm{~g}$ of $\mathrm{N} / \mathrm{kg}$ of $\mathrm{BW}^{0.75}$ to provide $1.80 \mathrm{~g}$ of $\mathrm{N} / \mathrm{kg}$ of $\mathrm{BW}^{0.75}$ in the TMR. Casein is a degradable source of peptides and AA. Peptides from casein are intermediates in ruminal protein degra- dation and often show transitory accumulation in the rumen (Chen et al., 1987; Broderick and Wallace, 1988). Dipeptides are probably the predominant products of proteolysis encountered by ruminal microbes, and their uptake and utilization rate varies for different rumen microorganisms (Yang, 2002). It has been reported that valine and leucine dipeptides were more rapidly used by ruminal bacteria than most other tested dipeptides containing single valine or leucine molecules when energy was available (Yang and Russell, 1992). This would explain the increase in microbial protein synthesis for less-fibrous and more energy-dense diets, and also the reduction in $\mathrm{NH}_{3}-\mathrm{N}$ observed in diets with lower incorporation of HS, substrates that are less readily fermentable in the rumen, provoking utilization of casein for energy purposes.
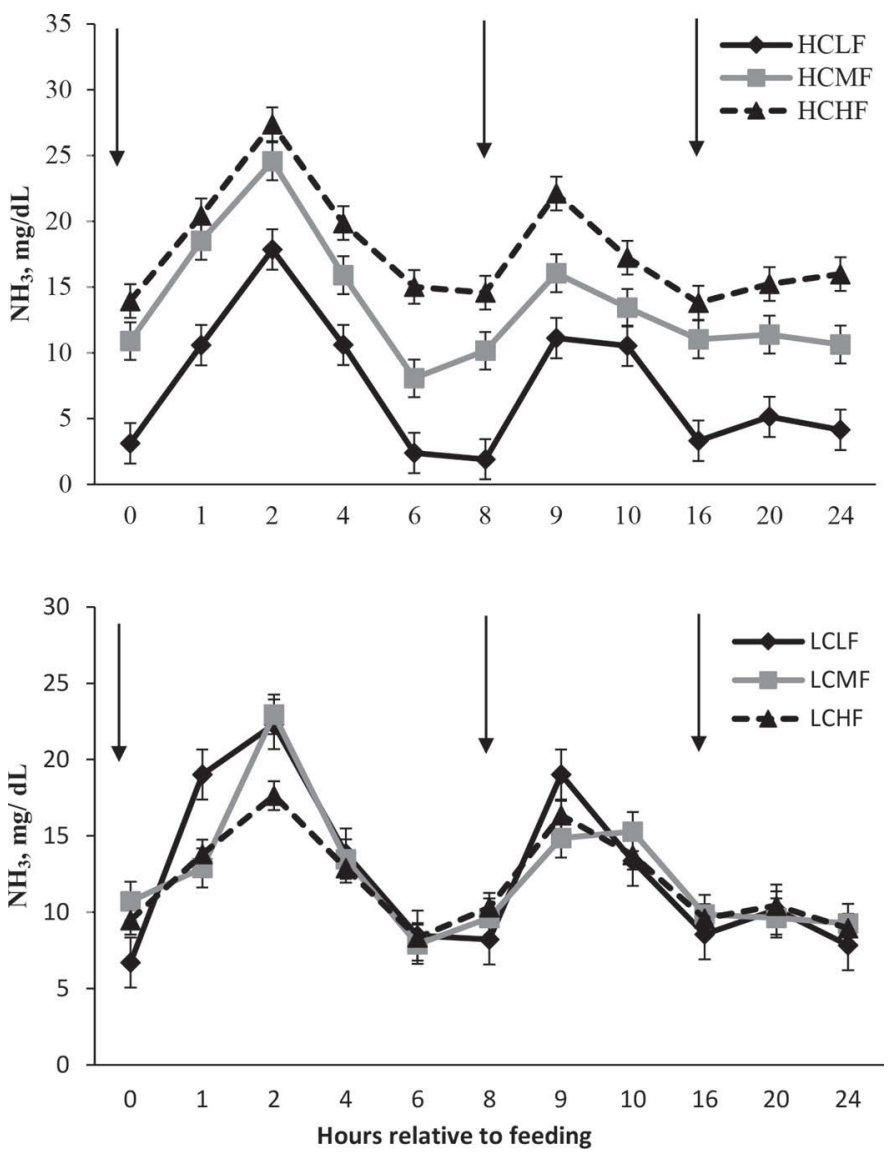

Figure 3. Diurnal rumen $\mathrm{NH}_{3}-\mathrm{N}$ concentration of dairy heifers fed differing forage-to-concentrate ratios (F:C) as low- (LC) or highconcentrate $(\mathrm{HC})$ diets containing 3 proportions of fiber through the incorporation of fibrous feedstuffs [33\%, low fiber (LF), $50 \%$, medium fiber (MF), or $67 \%$, high fiber (HF) in the 45 or $90 \%$ forage fraction of the diet]. Arrows represent feeding time. 


\section{Ruminal $\mathrm{pH}$}

Mean $\mathrm{pH}$ was not different among $\mathrm{F}$ : $\mathrm{C}$, but we observed a consistently lower diurnal $\mathrm{pH}$ for LF (Figure 2; $P=0.21)$ that resulted in a tendency for a greater area under the curve in which $\mathrm{pH}$ remained under 6.4 (Table 7). This is a result of the greater total concentration of VFA in the rumen; Yang (2002) reported a decrease in ruminal $\mathrm{pH}$ when VFA were not absorbed. Lascano and Heinrichs (2009) did not observe differences in heifers precision-fed different $\mathrm{F}$ : $\mathrm{C}$ containing solely $\mathrm{CS}$, although average $\mathrm{pH}$ was $<6.0$; VFA are more readily absorbed at lower $\mathrm{pH}$ and more easily diffused through the rumen wall in their undissociated form (Dijkstra et al.,1993). Therefore, accumulation of VFA for LF and slower absorption rate could be responsible for the lower $\mathrm{pH}$ exhibited by this $\mathrm{F}$ : C treatment.

We noted a linear increase in average $\mathrm{pH}$ and linear tendency $(P=0.10)$ in the area under the curve in which $\mathrm{pH}$ remained under 6.4 as HS was increased in diets, reflecting the decrease in molar proportion of propionate which has a higher pKa (acid dissociation constant) than acetate, which decreased linearly as HS was added to diets. Increasing dietary fiber through inclusion of a more fibrous feedstuff, such as HS, results in greater physically effective NDF, which has been associated with increased chewing activity while eating and ruminating (Mertens, 1997). This, at the same time, increases salivary secretion and the buffering capacity in the ruminant animal, explaining the effect in ruminal $\mathrm{pH}$ observed in the present study.

\section{Blood Metabolites}

Blood metabolites were measured for $24 \mathrm{~h}$ after the 1000-h feeding and there was a significant time effect for BUN $(P \leq 0.01)$ but not for glucose (Table 7$)$. A decrease in $\mathrm{F}: \mathrm{C}$ in the diet often results in higher blood glucose (Dhiman et al., 1991), but this has not been the case for experiments when the diets offered were isocaloric (Huntington, 1989). Diets with different F:C did not affect diurnal BUN or glucose concentrations in the present study. Similar results were observed when dairy heifers were limit fed and $\mathrm{F}$ :C reduced compared with the control (Kruse et al., 2010). In the present study, BUN increased linearly $(P \leq 0.02)$ as HS was incorporated in diets fed to dairy heifers. When degradation rates of total NSC have been reduced, similar to when HS replaces CS, an increase in BUN has been reported in dairy cows (Lykos et al., 1997); this effect is closely related to ruminal $\mathrm{NH}_{3}-\mathrm{N}$ (Figure 3 and 4 ) and resembles $\mathrm{N}$ retention observed in this experiment. A significant linear interaction was observed, where LF diets had increased BUN concentration throughout the day whereas HF-fed heifers did not change. Higher BUN concentrations observed with increased HS can be explained by increased absorption of ruminal $\mathrm{NH}_{3}-\mathrm{N}$, resulting in greater quantities of $\mathrm{NH}_{3}-\mathrm{N}$ being detoxified in the liver to form urea $\mathrm{N}$ (Huntington, 1989).

\section{Rumen Contents and volume}

We found no difference in rumen mass, volume, density, or in the fluid or solid fraction between F:C diets (Table 8). This is in agreement with Kruse et al. (2010), who reported no differences in these parameters measured during a growth phase of $180 \mathrm{~d}$ in dairy heifers fed 100,85 , or $80 \%$ of the control diet by modifying F:C. A numerical linear trend was noted toward a decrease in the fluid fraction and an increase in the solid fraction as HS was added in the diets (Table 8).

There was a tendency for a greater DM turnover rate for $\operatorname{LF}$ diets $(P=0.09)$. This is in agreement with
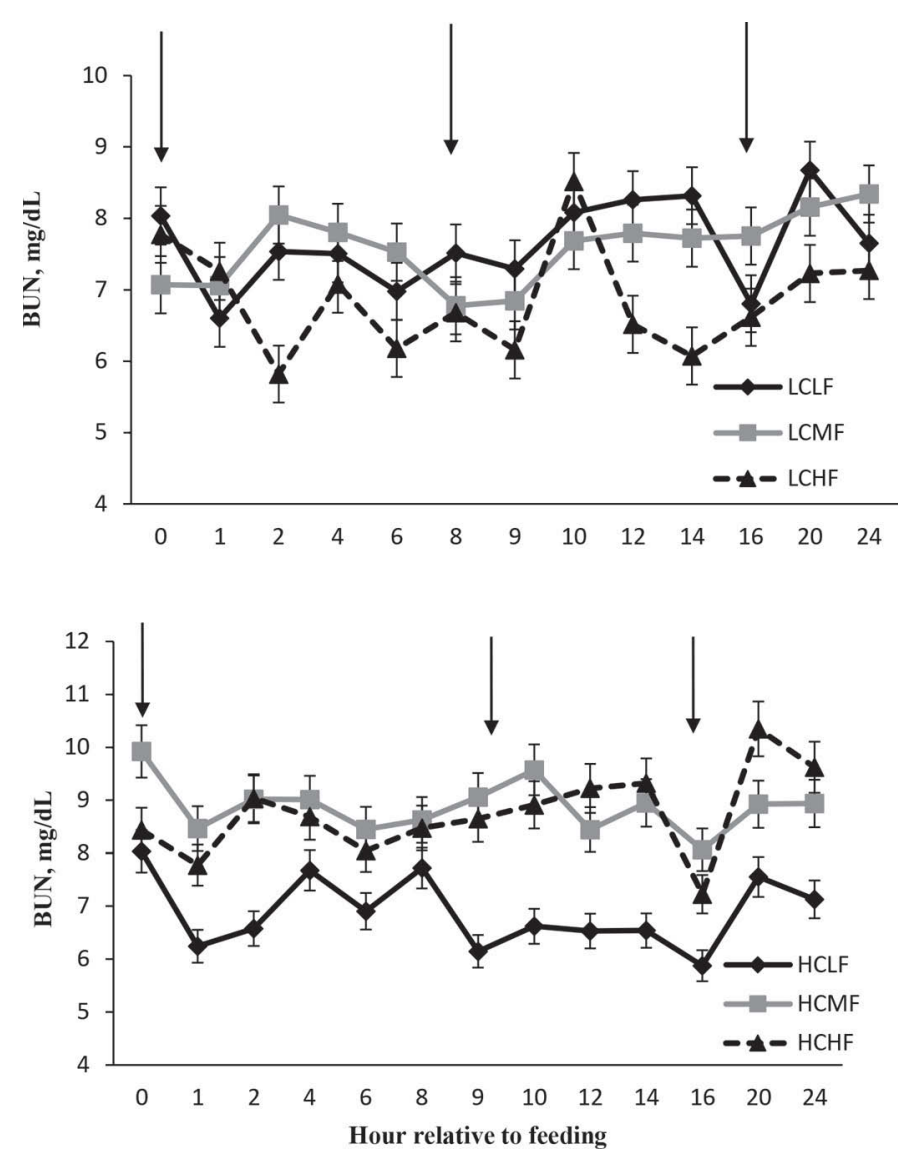

Figure 4. Diurnal BUN concentration of dairy heifers fed differing forage-to-concentrate ratios $(\mathrm{F}: \mathrm{C})$ as low- $(\mathrm{LC})$ or high-concentrate (HC) diets containing 3 proportions of fiber through the incorporation of fibrous feedstuffs $[33 \%$, low fiber (LF), $50 \%$, medium fiber (MF), or $67 \%$, high fiber (HF) in the 45 or $90 \%$ forage fraction of the diet]. Arrows represent feeding times. 
Table 8. Rumen pool sizes of whole rumen contents, DM, liquid, and volume of dairy heifers fed differing forage-to-concentrate ratios (F:C) as low- (LF) or high-forage (HF) diets containing 3 proportions of fiber through the incorporation of fibrous feedstuffs $(33,50$, or $67 \%$ in the 45 or $90 \%$ forage fraction of the diet)

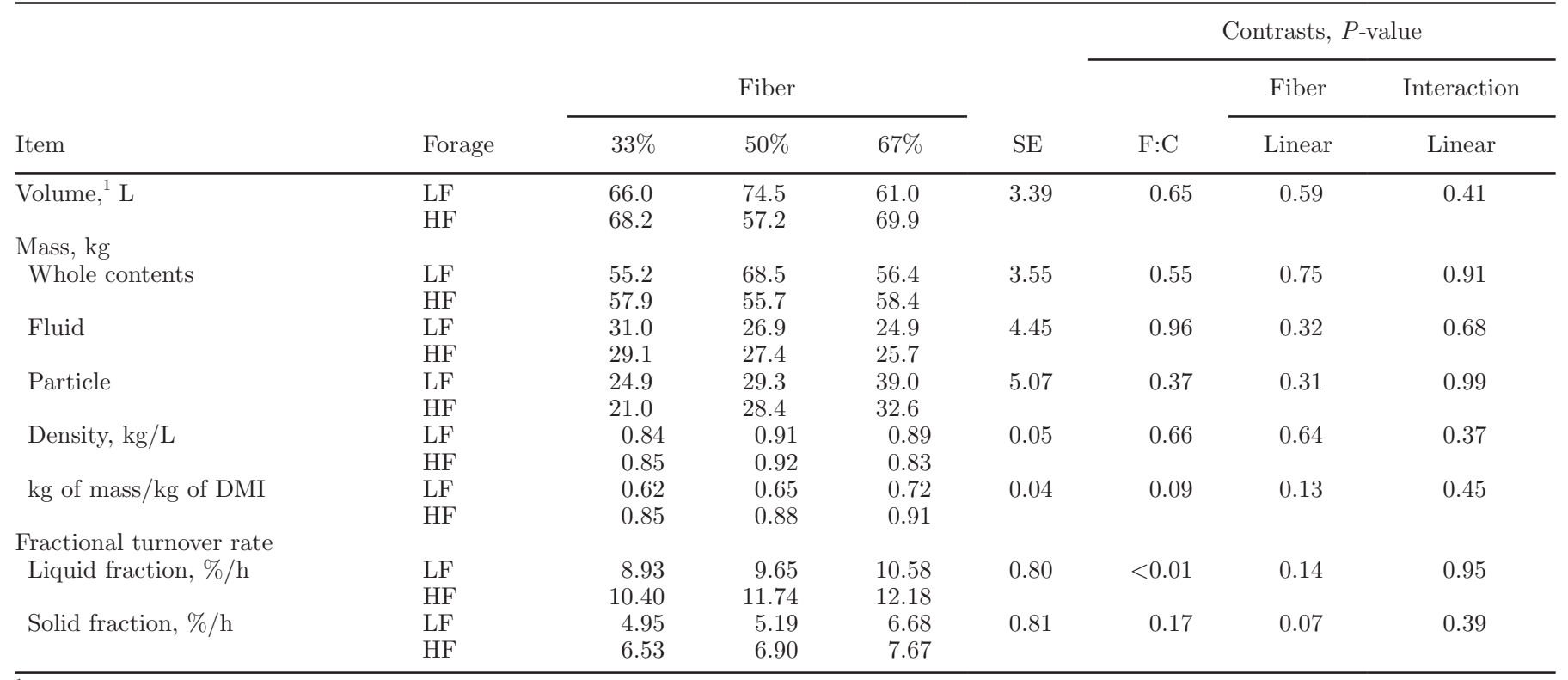

${ }^{1}$ Rumen volume was measured by marking the level of rumen contents on a plastic container.

other experiments where dairy heifers have been precision fed different F:C (Moody et al., 2007; Lascano and Heinrichs, 2009). It has been shown that when higher amounts of fiber are being fed to animals from forages, particle size is greater, and the time that these particles stay in the rumen is longer due to a reduction in the passage rate of fiber (Jung and Allen, 1995). Under an ad libitum feeding system, rate of passage is higher when greater proportions of concentrates are fed in comparison to diets containing a higher concentration of forages (Colucci et al., 1990; Van Soest, 1994). But when intake is controlled and fed precisely to meet the animal's requirement to attain a targeted ADG or milk production, ruminal retention time is greater as intake is decreased (Eng et al., 1964; Colucci et al., 1989; Murphy et al., 1994).

Rumen retention time of digesta can also be affected by F:C; Lascano and Heinrichs (2009) reported a linear decrease in rumen retention when dairy heifers were fed restricted intakes of diets containing 80:20, 60:40, and 40:60 F:C. When different daily intakes were compared in dairy cows fed different F:C, higher intake yielded lower rumen retention times and lower $\mathrm{dC}$, and these parameters were decreased linearly as the $\mathrm{F}$ :C offered to the animals were 80:20, 55:45, and 30:70 (Colucci et al., 1989). The flow of liquid, small, and large particles from the rumen was increased when greater amounts of DM were offered to animals (Owens and Goetsch, 1988). This is in agreement with the results from the present experiment where, as intakes were increased liquid fraction turnover rate increased between $\mathrm{F}: \mathrm{C}(P$ $<0.01)$ and tended to increase $(P=0.14)$ as fiber was added to the diets. On the other hand, the solid fraction turnover rate was not affected by $\mathrm{F}$ : C treatment, but addition of HS tended to linearly increase $(P=$ $0.07)$ turnover rate of this fraction. Thus, to increase the efficiency at which nutrients are being used by the animal and fermented by microbes in the rumen, an optimal balance between fiber, NSC, protein, and F:C is required when animals are precision-fed is necessary.

\section{CONCLUSIONS}

Increasing dietary fiber proportions in precisionfed dairy heifers was used to determine the effects on nutrient utilization and $\mathrm{N}$ efficiency and whether it was altered by protein degradability and $\mathrm{F}: \mathrm{C}$ ratio. As expected, LF diets had the highest apparent total-tract digestibility of nutrients. Diets with the lower proportion of fiber benefited the most of a high RDP, complementing microbial protein synthesis to improve protein utilization and rumen fermentation; higher fiber proportions reduced $\mathrm{N}$ and nutrient utilization, with complementary effects observed for rumen fermentation. A greater fractional rate of passage decreased nutrient digestion, microbial synthesis, and ruminal fermentation, resulting in an inefficient use of nutrients provided when dietary fiber was proportionally increased whereas RDP remained constant. When dairy heifers were fed an HF diet, heifers fed low fiber 
benefited at a lower rate in the same manner as the LF-fed group as a result of having a higher dietary concentration of RDP. Predicted microbial protein flow to the duodenum decreased linearly with HS addition, resulting in a linear decrease in $\mathrm{N}$ retention with $\mathrm{HS}$ addition; this was opposite to ruminal $\mathrm{NH}_{3}-\mathrm{N}$ and BUN, reflecting the inefficiency in $\mathrm{N}$ utilization as more HS was added to the diets. Rumen fermentation parameters, DM turnover, and fractional passages (solid and liquid) rates support the reduction in digestibility, $\mathrm{N}$ retention, and microbial protein synthesis observed as more dietary fiber is added to the rations of dairy heifers precision-fed a constant content of RDP. Therefore, we can conclude that precision-fed dairy heifers use nutrients in LF diets more efficiently, and additional dietary fiber depressed microbial protein synthesis and nutrient and $\mathrm{N}$ utilization under high proportions of RDP. Higher RUP seemed to be necessary to complement low fermentation potential when additional fiber is added under these conditions.

\section{ACKNOWLEDGMENTS}

Appreciation is extended to M. R. Long for laboratory assistance, to D. D. Maulfair, F. X. Suarez-Mena, and K. K. McIntyre (all of Penn State) for assistance with animals and data collection, and to C. M. Jones of Penn State and A. E. Goho of Clemson University (Clemson, SC) for editorial assistance.

\section{REFERENCES}

AOAC International. 2000. Official Methods of Analysis. 15th ed. AOAC International, Arlington, VA.

Bach, A., S. Calsamiglia, and M. D. Stern. 2005. Nitrogen metabolism in the rumen. J. Dairy Sci. 88:E9-E21.

Beckman, J. L., and W. P. Weiss. 2005. Nutrient digestibility of diets with different fiber to starch ratios when fed to lactating dairy cows. J. Dairy Sci. 88:1015-1023.

Bourquin, L. D., E. C. Titgemeyer, J. Van Milgen, and G. C. Fahey Jr. 1994. Forage level and particle size effects on orchardgrass digestion by steers: II. Ruminal digestion kinetics of cell wall components. J. Anim. Sci. 72:759-767.

Broderick, G. A., and R. J. Wallace. 1988. Effects of dietary nitrogen source on concentration of ammonia, free amino acids and fluorescamine-reactive peptides in the sheep rumen. J. Anim. Sci. 66:2233-2238.

Brossard, L., F. Chaucheyras-Durand, B. Michalet-Doreau, and C. Martin. 2006. Dose effect of live yeasts on rumen microbial communities and fermentations during butyric latent acidosis in sheep: New type of interaction. Anim. Sci. 82:829-836.

Brossard, L., C. Martin, and B. Michalet-Doreau. 2003. Ruminal fermentative parameters and blood acid-basic balance changes during the onset and recovery of induced latent acidosis in sheep. Anim. Res. 52:513-530.

Brown, M. S., C. H. Ponce, and R. Pulikanti. 2006. Adaptation of beef cattle to high-concentrate diets: Performance and ruminal metabolism. J. Anim. Sci. 84:E25-E33.

Calsamiglia, S., P. W. Cardozo, A. Ferret, and A. Bach. 2008. Changes in rumen microbial fermentation are due to a combined effect of type of diet and pH. J. Anim. Sci. 86:702-711.
Carro, M. D., C. Valdes, M. J. Ranilla, and J. S. Gonzalez. 2000. Effect of forage to concentrate ratio in the diet on ruminal fermentation and digesta flow kinetics in sheep. Anim. Sci. 70:127-134.

Chen, G., C. J. Sniffen, and J. B. Russell. 1987. Concentration and estimated flow of peptides from the rumen of dairy cattle: Effects of protein solubility and feeding frequency. J. Dairy Sci. 70:983-992.

Chen, X. B., and M. J. Gomes. 1992. Estimation of Microbial Protein Supply to Sheep and Cattle Based on Urinary Excretion of Purine Derivatives: An Overview of Technical Details. Rowett Research Institute, Aberdeen, UK.

Clark, J. H., T. H. Klusmeyer, and M. R. Cameron. 1992. Microbial protein synthesis and flows of nitrogen fractions to the duodenum of dairy cows. J. Dairy Sci. 75:2304-2323.

Coe, M. L., T. G. Nagaraja, Y. D. Sun, N. Wallace, E. G. Towne, K. E. Kemp, and J. P. Hutcheson. 1999. Effect of virginiamycin on ruminal fermentation in cattle during adaptation to a high concentrate diet and during an induced acidosis. J. Anim. Sci. 77:2259-2268.

Colucci, P. E., G. K. Macleod, W. L. Grovum, L. W. Cahill, and I. McMillan. 1989. Comparative digestion in sheep and cattle fed different forage to concentrate ratios at high and low intakes. J. Dairy Sci. 72:1774-1785.

Colucci, P. E., G. K. MacLeod, W. L. Grovum, I. McMillan, and D. J. Barney. 1990. Digesta kinetics in sheep and cattle fed diets with different forage to concentrate ratios at high and low intakes. J. Dairy Sci. 73:2143-2156.

Dehority, B. A., and C. G. Orpin. 1988. Development of, and natural fluctuations in, rumen microbial populations. Pages 151-183 in The Rumen Microbial Ecosystem. P. N. Hobson, ed. Elsevier, London, UK.

Dhiman, T. R., J. Kleinmans, N. J. Tessmann, H. D. Radloff, P. van Everet, and L. D. Satter. 1991. Effect of dietary forage:grain ratio on blood constituents in dairy cows. J. Dairy Sci. 74:2691-2695.

Dijkstra, J., H. Boer, J. Van Bruchem, M. Bruining, and S. Tamminga. 1993. Absorption of volatile fatty acids from the rumen of lactating dairy cows as influenced by volatile fatty acid concentration, pH and rumen liquid volume. Br. J. Nutr. 69:385-396.

Eng, K. S., J. C. Smith, J. H. Craig, and M. E. Riewe. 1964. Rate of passage of concentrate and roughage through digestive tract of sheep. J. Anim. Sci. 23:1129-1132.

Eun, J.-S., V. Fellner, and M. L. Gumpertz. 2004. Methane production by mixed ruminal cultures incubated in dual-flow fermenters. J. Dairy Sci. 87:112-121.

Firkins, J. L., M. L. Eastridge, N. R. St-Pierre, and S. M. Noftsger. 2001. Effects of grain variability and processing on starch utilization by lactating dairy cattle. J. Anim. Sci. 79:E218-E238.

Fuentes, M. C., S. Calsamiglia, P. W. Cardozo, and B. Vlaeminck. 2009. Effect of $\mathrm{pH}$ and level of concentrate in the diet on the production of biohydrogenation intermediates in a dual-flow continuous culture. J. Dairy Sci. 92:4456-4466.

Gabler, M. T., and A. J. Heinrichs. 2003. Effects of increasing dietary protein on nutrient utilization in heifers. J. Dairy Sci. 86:21702177.

Galyean, M. L., and P. J. Defoor. 2003. Effects of roughage source and level on intake by feedlot cattle. J. Anim. Sci. 81:E8-E16.

Grovum, W. L., and V. J. Williams. 1973. Rate of passage of digesta in sheep. 1. The effect of level of feed intake on marker retention times along the small intestine and on apparent water absorption in the small and large intestines. Br. J. Nutr. 29:13-21.

Guan, L. L., J. D. Nkrumah, J. A. Basarab, and S. S. Moore. 2008. Linkage of microbial ecology to phenotype: correlation of rumen microbial ecology to cattle's feed efficiency. FEMS Microbiol. Lett. 288:85-91.

Halevi, A., H. Neumark, and S. Amir. 1973. Straw in different proportions as sole roughage in diets for cows in mid-lactation. J. Dairy Sci. 56:1424-1428.

Hoover, W. H., and S. R. Stokes. 1991. Balancing carbohydrates and proteins for optimum rumen microbial yield. J. Dairy Sci. 74:3630 3644 .

Hristov, A. N., J. K. Ropp, K. L. Grandeen, S. Abedi, R. P. Etter, A. Melgar, and A. E. Foley. 2005. Effect of carbohydrate source on 
ammonia utilization in lactating dairy cows. J. Anim. Sci. 83:408 421.

Hungate, R. E. 1966. The Rumen and its Microbes. Academic Press, New York, NY.

Huntington, G. B. 1989. Hepatic urea synthesis and site and rate of urea removal from blood of beef steers fed alfalfa hay or a high concentrate diet. Can. J. Anim. Sci. 69:215-223.

Johnson, L. M., J. H. Harrison, and R. E. Riley. 1998. Estimation of the flow of microbial nitrogen to the duodenum using urinary uric acid or allantoin. J. Dairy Sci. 81:2408-2420.

Jung, H. G., and M. S. Allen. 1995. Characteristics of plant cell walls affecting intake and digestibility of forages by ruminants. J. Anim. Sci. 73:2774-2790

Keys, J. E., and W. Smith. 1981. Effects of dried poultry excreta on growth, intake, and digestion of corn stover silage diets by yearling dairy heifers. J. Dairy Sci. 64:211-216.

Kitts, B. L., I. J. H. Duncan, B. W. McBride, and T. J. DeVries. 2011 Effect of the provision of a low-nutritive feedstuff on the behavior of dairy heifers fed a high-concentrate ration in a limited amount. J. Dairy Sci. 94:940-950.

Kruse, K. A., D. K. Combs, N. M. Esser, W. K. Coblentz, and P. C. Hoffman. 2010. Evaluation of potential carryover effects associated with limit feeding of gravid Holstein heifers. J. Dairy Sci. 93:5374-5384.

Lammers, B. P., and A. J. Heinrichs. 2000. The response of altering the ratio of dietary protein to energy on growth, feed efficiency, and mammary development in rapidly growing prepubertal heifers. J. Dairy Sci. 83:977-983.

Lascano, G. J., and A. J. Heinrichs. 2009. Rumen fermentation pattern of dairy heifers fed restricted amounts of low, medium, and high concentrate diets without and with yeast culture. Livest. Sci. 124:48-57.

Lascano, G. J., and A. J. Heinrichs. 2011. Effects of feeding different levels of dietary fiber through the addition of corn stover on nutrient utilization of dairy heifers precision-fed high and low concentrate diets. J. Dairy Sci. 94:3025-3036.

Lascano, G. J., G. I. Zanton, and A. J. Heinrichs. 2009b. Concentrate levels and Saccharomyces cerevisiae affect rumen fluid-associated bacteria numbers in dairy heifers. Livest. Sci. 126:189-194.

Lascano, G. J., G. I. Zanton, A. J. Heinrichs, and W. P. Weiss. 2010. Technical note: A non-invasive urine collection device for female cattle: Modification of the urine cup collection method. J. Dairy Sci. 93:2691-2694.

Lascano, G. J., G. I. Zanton, F. X. Suarez-Mena, and A. J. Heinrichs. 2009a. Effect of limit feeding high- and low-concentrate diets with Saccharomyces cerevisiae on digestibility and on dairy heifer growth and first-lactation performance. J. Dairy Sci. 92:5100-5110.

Littell, R. C., P. R. Henry, and C. B. Ammerman. 1998. Statistical analysis of repeated measures data using SAS procedures. J. Anim. Sci. 76:1216-1231.

Lykos, T., G. A. Varga, and D. Casper. 1997. Varying the degradation rates of total nonstructural carbohydrates: Effects on ruminal fermentation, blood metabolites, and milk production and composition in high producing Holstein cows. J. Dairy Sci. 80:3341-3355.

Meng, Q., M. S. Kerley, P. A. Ludden, and R. L. Belyea. 1999. Fermentation substrate and DR interact to affect microbial growth and efficiency. J. Anim. Sci. 77:206-214.

Merchen, N. R., and E. C. Titgemeyer. 1992. Manipulation of amino acid supply to the growing ruminant. J. Anim. Sci. 70:3238-3247.

Mertens, D. R. 1997. Creating a system for meeting the fiber requirements of dairy cows. J. Dairy Sci. 80:1463-1481.

Moody, M. L., G. I. Zanton, J. M. Daubert, and A. J. Heinrichs. 2007. Nutrient utilization of differing forage to concentrate ratios by growing Holstein heifers. J. Dairy Sci. 90:5580-5586.
Murphy, T. A., F. L. Fluharty, and S. C. Loerch. 1994. The influence of intake level and corn processing on digestibility and ruminal metabolism in steers fed all-concentrate diets. J. Anim. Sci. $72: 1608-1615$.

Nocek, J. E., and J. B. Russell. 1988. Protein and energy as an integrated system relationship of ruminal protein and carbohydrate availability to microbial synthesis and milk production. J. Dairy Sci. 71:2070-2107.

NRC. 2001. The Nutrient Requirements of Dairy Cattle. 7 Rev. ed Nat. Acad. Press, Washington DC.

Ogimoto, K., and S. Imai. 1981. Atlas of Rumen Microbiology. Japan Scientific Societies Press, Tokyo, Japan.

Owens, F. N., and A. L. Goetsch. 1988. Ruminal fermentation. Pages 145-171 in The Ruminant Animal, Digestive Physiology and $\mathrm{Nu}-$ trition. D. C. Church, ed. Prentice-Hall, Englewood Cliffs, NJ.

Owens, F. N., and H. R. Isaacson. 1977. Ruminal microbial yields: Factors influencing synthesis and bypass. Fed. Proc. 36:198-202.

Penner, G. B., J. R. Aschenbach, G. Gäbel, R. Rackwitz, and M. Oba. 2009. Epithelial capacity for apical uptake of short chain fatty acids is a key determinant for intraruminal $\mathrm{pH}$ and the susceptibility to subacute ruminal acidosis in sheep. J. Nutr. 139:1714-1720.

Pina, D. S., S. C. Valadares, L. O. Tedeschi, A. M. Barbosa, and R. F. D. Valadares. 2009. Influence of different levels of concentrate and ruminally undegraded protein on digestive variables in beef heifers. J. Anim. Sci. 87:1058-1067.

Ramos, S., M. L. Tejido, M. E. Martínez, M. J. Ranilla, and M. D. Carro. 2009. Microbial protein synthesis, ruminal digestion, microbial populations, and nitrogen balance in sheep fed diets varying in forage-to-concentrate ratio and type of forage. J. Anim. Sci. 87:2924-2934

Russell, J. B., C. J. Sniffen, and P. J. Van Soest. 1983. Effect of carbohydrate limitation on degradation and utilization of casein by mixed rumen bacteria. J. Dairy Sci. 66:763-775.

Storm, E., and E. R. Orskov. 1983. The nutritive value of rumen microorganisms in ruminants. 1. Large-scale isolation and chemical composition of rumen microorganisms. Br. J. Nutr. 50:463-470.

Tajima, K., R. I. Aminov, T. Nagamine, H. Matsui, M. Nakamura, and Y. Benno. 2001. Diet-dependent shifts in the bacterial population of the rumen revealed with real time PCR. Appl. Environ. Microbiol. 67:2766-2774.

Udén, P., P. E. Colucci, and P. J. Van Soest. 1980. Investigation of chromium, cerium and cobalt as markers in digesta. Rate of passage studies. J. Sci. Food Agric. 31:625-632.

Valadares, R. F., G. A. Broderick, S. C. Valadares Filho, and M. K. Clayton. 1999. Effect of replacing alfalfa silage with high moisture corn on ruminal protein synthesis estimated from excretion of total purine derivatives. J. Dairy Sci. 82:2686-2696.

Van Soest, P. J. 1994. Nutritional Ecology of the Ruminant. 2nd ed. Comstock Publishing, Ithaca, NY.

Van Soest, P. J., J. B. Robertson, and B. A. Lewis. 1991. Methods for dietary fiber, neutral detergent fiber, and nonstarch polysaccharides in relation to animal nutrition. J. Dairy Sci. 74:3583-3597.

Yang, C.-M. J. 2002. Response of forage fiber degradation by ruminal microorganisms to branched-chain volatile fatty acids, amino acids, and dipeptides. J. Dairy Sci. 85:1183-1190.

Yang, C.-M. J., and J. B. Russell. 1992. Resistance of proline-containing peptides to ruminal degradation in vitro. Appl. Environ. Microbiol. 58:3954-3958.

Zanton, G. I., M. T. Gabler, and A. J. Heinrichs. 2007. Manipulation of soluble and rumen-undegradable protein in diets fed to postpubertal dairy heifers. J. Dairy Sci. 90:978-986.

Zanton, G. I., and A. J. Heinrichs. 2009. Digestion and nitrogen utilization in dairy heifers limit-fed a low or high forage ration at four levels of nitrogen intake. J. Dairy Sci. 92:2078-2094. 